\title{
AVALIAÇÃO DA RESISTENNCIA AO RAQUITISMO DA SOQUEIRA PELO MÉTODO DA VAZÃO DE ÁGUA EM COLMOS DE CANA-DE-AÇÚCAR
}

\author{
PEDRO JOSÉ VALARINI \\ ENG AGR - EMBRAPA
}

Prof. Dr. HASIME TOKESHI ORIENTADOR

Dissertação apresentada à Escola Superior de Agricultura "Luiz de Queiroz", da Universidade de São Paulo, para obtenção do título de Mestre em Fitopatólogia.

\footnotetext{
$P|R A C| C A B A$

Estado de São Paulo - Erasil junho, 1978
} 
. u.
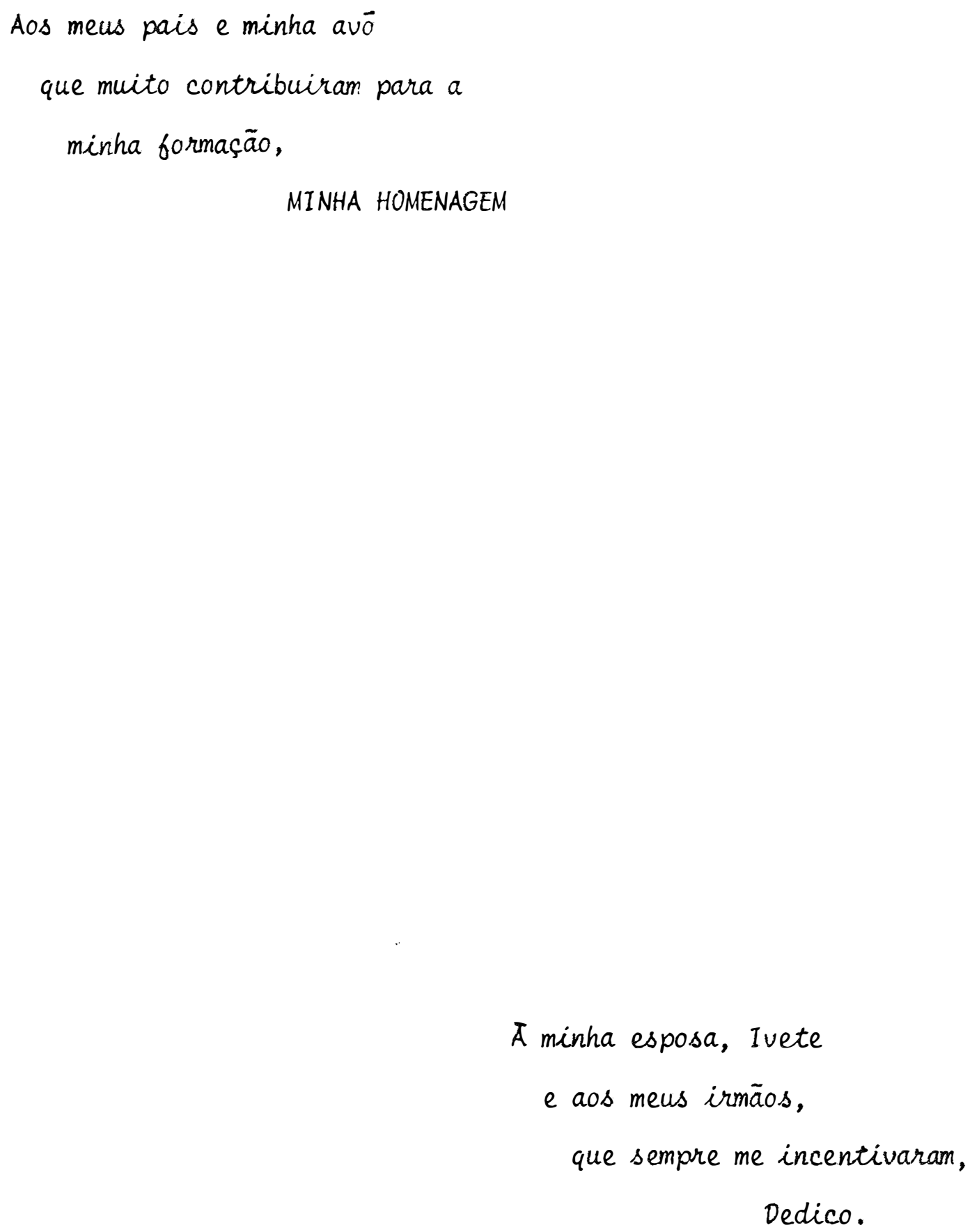
.iii.

\section{AGRADECIMENTOS}

0 autor externa os seus mais sinceros agradecimentos a todos que direta ou indiretamente contribuiram para a realização deste trabalho em especial àquelas relacionadas a seguir:

- A esposa Ivete R. Amstalden Valarini, pela paciência, dedí cação e destacada participação durante a desenvolvimento do presente traba1ho;

- Ao Prof. Dr. HASIME TOKESHI, pela valiosa orientação, amizade, entusiástico interesse e colaboração na minha formação cientifica,

- Ao Dr. FERDINANOO GALLI, chefe do Departamento de Fitopato logia, pelas facilidades oferecidas durante o desenvolvimento do curso e execução do trabalho;

- A Empresa Brasileira de Pesquisa Agropecuária (EMBRAPA) pela oportunidade concedida de aperfeiçoamento e apoio na realização do cur so:

- Ao Conselho Nacional de Desenvolvimento Cientifico e Tecno lógico (CNPq) pela concessão de bolsas de estudos

- Ao Prof. Dr. PAUlo ROBERTo de CASTRO pela colaboração ma revisão dos originais, críticas e sugestões apresentadas;

- Ao Planalsucar, e em especial do Dr. Sizuo Matsuoka, pela excelente colaboração no fornecimento de materiais de cana-de-açücar durante o desenvolvimento do trabalho; 
iv.

- A Estação Experimental da COPERSUCAR pela colaboração pres tada no fornecimento de materiais de cana-de-açūcar;

- A Engenheiro Agrônomo Maria José Valarini, pela valiosa co laboração na revisão final dos originais e sugestões apresentadas;

- Ao Dr. Humberto de Campos e ao Engenheiro Agrônomo Norberto Antonio Lavorenti, pela colaboração na análise estatística dos dados,

- Ao Dr. Gileno Maciel pela valiosa participação na elaboração dos desenhos:

- Ao Dr. Eiichi Matsui pela idealização e construção do vacuômetro de mercúrio;

- Aos Colegas do Curso de Pós-Graduação do Departamento de Fitopatologia da ESALQ, pelas sugestões prestadas na elaboração do trabalho;

- A Maria Elizabeth Ferreira de Carvalho e Luiz Carlos Verís simo, funcionários da biblioteca da ESALQ, pela valiosa colaboração na cita ção de literatura;

- A Sra. Sônia Novaes Rasera, pelo serviço de datilografia;

- Ao Sr. Alcideo Andrioli, funcionário do Departamento de Fi topatologia pela colaboração na coleta de material e nos trabalhos de laboratório. 


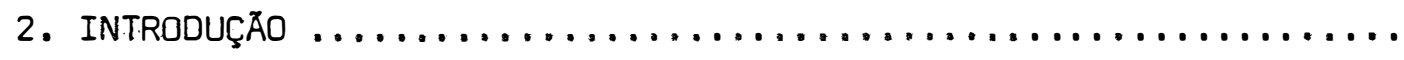

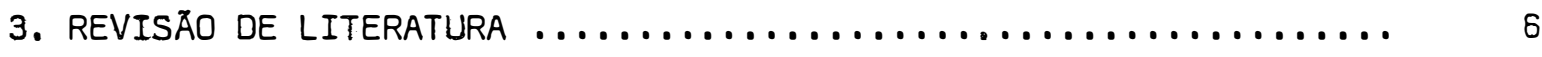

3.1. Agente causal e disseminação do patógeno $\ldots . . \ldots \ldots \ldots \ldots . .6$

3.2. Sintomas diagnósticos e interferência de fatores na expres

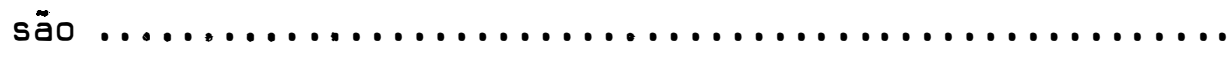

3.3. Diagnose através de testes biológicos, técnicas serológicas e microscópicas $\ldots \ldots \ldots \ldots \ldots \ldots \ldots \ldots \ldots \ldots \ldots \ldots \ldots \ldots$

3.4. Controle do Raquitismo da Soqueira (RS) $\ldots . . . \ldots \ldots \ldots \ldots$

3.5. Métodos de avaliação de doenças baseados na anatomia vascu

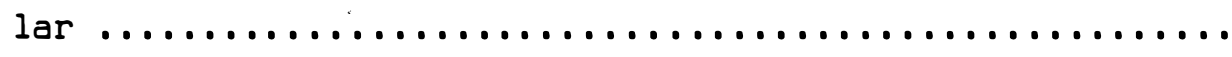

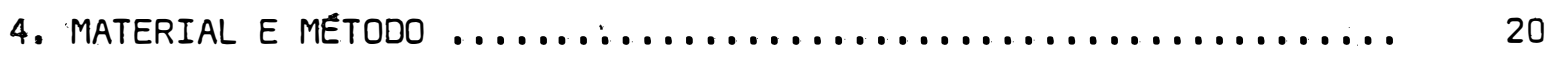

4.1. Método de avaliação do RS $\ldots \ldots \ldots \ldots \ldots \ldots \ldots \ldots \ldots \ldots \ldots . \ldots \ldots$

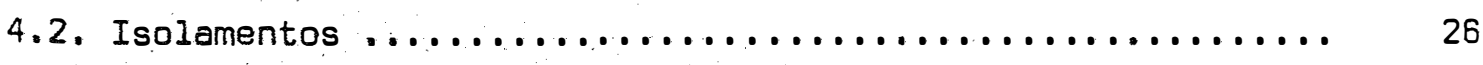

4.2.1. Isolamento de Fusarium moniliforme $\ldots \ldots \ldots \ldots \ldots$

4.2.2. Escaldadura das Folhas $\ldots \ldots \ldots \ldots \ldots \ldots \ldots \ldots \ldots \ldots$

4.3. Medidas dos diâmetros do lume dos vasos do xilema ........ 27

5. RESULTADOS .................................... 29

5.1. Fatores que interferem na avaliação do RS ............ 29 


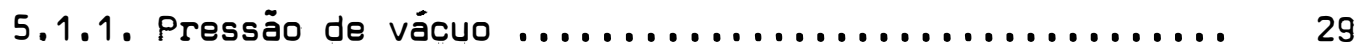

5.1.2. Sentido do colmo ....................... 30

5.1.3. Localização dos nós no colmo ............... 32

5.1.4. Armazenamento dos colmos .................. 34

5.1.5. Correlação positiva entre a vazão e o número de va-

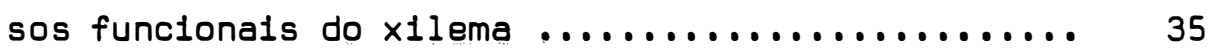

5.1.6. Distribulção do RS dentro de toucelra de cana-de-a-

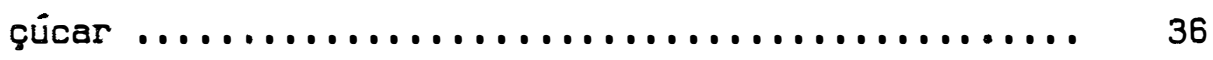

5.2. Isolamentos de contaminantes dos vasos do $\times 1$ lema ........ 40

5.3. Resultados de aplicação do método de vazão de água ....... 41

5.3.1. Evolução da Infestação de RS em cana-planta e cana

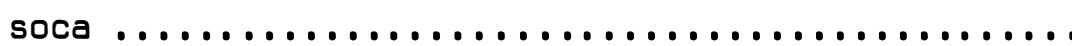

5.3.2. Avallação da vazão de água em colmos de cana-de-açú car tratados termicamente e inoculados com RS .....

5.4. Medidas dos diâmetros do lume dos vasos do xilema de colmos de cana-de-açūcar $\ldots \ldots \ldots \ldots \ldots \ldots \ldots \ldots \ldots \ldots \ldots \ldots \ldots$

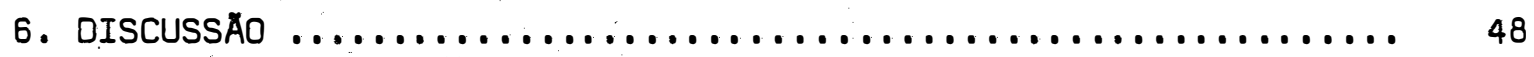

6.1. Fatores que 1nterferem no método de avallação do RS ...... 48

6.2. Apilicaçào do método de vazão de água para avaliação do RS. 53

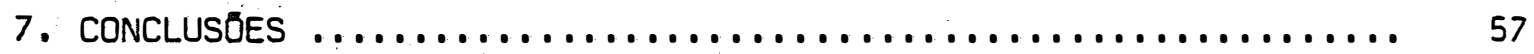

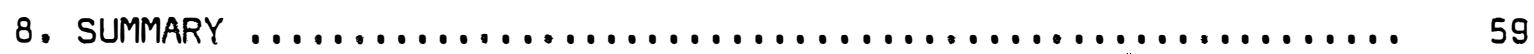


.vii.

pāgina

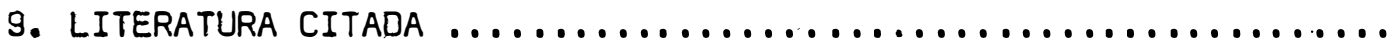




\section{RESUMO}

O controle do Raquitismo da Soqueira (RS) tem sido Insatisfa tório devido as dificuldades de 1dentificação da doença e ausêncla de sinto mas especificos não questionáve1s. o "roguing" usado com sucessó no contro le de outras doenças da cana-de-açúcar é Impossível de ser aplicado sem um sintoma externo especifico. O desenvolvimento das cultivares resistentes ao RS é diffcil devido a ausêncla de método rápldo e eflclente de seleção.

Objetivando résolvẹ o problema desenvolveu-se o método de medida de vazão de água em colmos de cana-de-açūcar. A água fo1 passada através de colmos de cana-de-açúcar sadios e doentes. O efeito do RS na vazão fol avaliado nas cultivares comerclals e diferenclals para RS. Estudou-se o efeito de diversos fatores em vazão de colmos sadios e doentes sob vá cuo constante.

Os resultados mostraram que, com exceção do diâmetro do colmo, os fatores armazenamento, pressão de vácuo, sent1do do colmo, local1zação do nó no colmo, 1dade do colmo, distribulção da doença dentro da touce1 
ra, colmos injuriados por Diatraea saccharalis e outras doenças vasculares Interferem na avallação da vazão do colmo.

As análises estatisticas dos dados de vazão lndicaram que nas cultivares tolerantes ao RS a queda de vazão de água entre colmos sadios e doentes fol pequena, jä nas cultivares suscetiveis observou-se o oposto.

Determinou-se também a existêncla de correlação entre queda de vazão, presença de sintomas de RS nos nós e menor número de feixes vascu lares funcionais. Concluiu-se que a determinação de vazão de água em colmos sadios e doentes poderá constituir-se num método eficiente, seguro, rápido e econômico de seleção de plantas resistentes ao RS e de outras doenças vasculares em cana-de-açücar. 


\section{INTRODUÇAOO}

A cana-de-açúcar é considerada, mundialmente, uma das culturas mals bem dotadas, pela sua alta capacidade de difusão geográfica, pelo seu enorme valor econômico-social e pelas inúmeras indústrias qué carrela consigo.

Atualmente, entre os palses produtores de cana-de-açúcar, des taca-se o Brasil como o malor produtor, onde verifica-se, de ano para ano, um crescimento nesse setor, prevendo-se para a safra $77 / 78$ uma produção de 135 milhöes de sacas de açúcar e cerca de 1587 milhöes de litros de álcool (IAA-1977). Por outro lado, no momento, en razão da grande expansão na pro dução de álcool para os próximós anos, hả enorme interesse dos produtores em aumentar as áreas de plantio de cana-de-açúcar (Prognóstico 77/78 - Instituto de Pesquisas Econômicas da Secretaria da Agricultura do Estado de São. Paulo\}.

Apesar de ser o malor produtor de açúcar de cana, a produt1vidade agrícola brasileira é inferior a de outros palses competidores, pois 
.4 .

a sua produtividade por unidade de área, equivale a $70 \%$ da produtividade da Africa do Sul, Austrália e Estados Unidos Continental e $40 \%$ da produtividade do Haval. Como pode-se verificar, essas cifras espelham que muitos fato res podem estar contribuindo para a baixa produtividade brasileira de cana-de-açúcar.

As possibilidades de melhoria da produção e da produtividade da cultura da cana-de-açücar são muito grandes, se levarmos em consideração o aumento do potencial genético das cultivares, o uso racional das práticas agricolas e, principalmente, o combate das doenças e pragas.

Dos numerosos problemas fitossanitários que atingem a cana-de-açúcar, trazendo considerável queda de produção, é de maior importância a doença Raquitismo da Soqueira (RS). Apesar da real importâncià da doença, desconhece-se o quanto de perda agrícola e industrial é devido ao RS. A li teratura nacional consultada apresenta apenas alguns dados estimados que, muitas vezes, se baseiam em dados fornecidos pela literatura estrangeira. 0 maior entrave envolvido neste aspecto se relaciona a não disponibilidade de uma cultivar testemunha verdadeirà, devido à ausência de métodos adequados de cura e do controle de reinfestação com RS na cultura.

Atualmente, a inativação do agente causal pelo calor é o método mais eficiente de controle do RS, mas tem sido apenas uma prática paliativa e de custo elevado. Por outro lado, os métodos de melhoramento empregados, só permitem a obtenção das cultivares tolerantes oụ resistentes ao RS, por mero acaso, pois as seleções não são dirigidas diretamente para este objetivo. 
Com os conhecimentos atuais, a identificação e controle do RS são considerados difíceis e problemáticos. Decorre dal a necessidade de se desenvolver uma nova metodologia de trabalho, que possibilite avaliar o efeito da moléstia na cana-de-açúcar.

Os objetivos principais do trabalho compreendem basicamente, determinar a ocorrêncla de correlação entre a vazão de água em colmos de ca na-de-açúcar e o grau de suscetibilidade das cultivares ao RS e estudar alguns fatores que interferem nesta determinação. Procurou-se desenvolver um método simples, preciso, rápido e seguro de avaliar cultivares sensíveis ao RS, sem a necessidade de observar a queda de produção de canas soca e resso ca.

0 presente trabalho foi desenvolvido no Departamento de Fito patologia da ESALQ/USP e as cultivares de cana-de-açúcar foram fornecidas pelas Estaçöes Experimentais da COPERSUCAR (Piracicaba - SP) e PLANALSUCARIAA (Araras-SP). 


\section{REVISAOO DE LITERATURA}

\subsection{Agente causal e disseminação do patógeno}

O Raquitismo da Soqueira (RS) foi observado, pela primeira vez, em Queensland (Austrália), nos anos de 1944 - 1945, incidindo sobre a variedade Q28, a qual apresentava um crescimento sub-normal e irregular (HE GHES e STEINDL, 1955). Entretanto, no Brasil, somente fol constatado, inicialmente, por VEIGA (1956), em Campos (RJ) e por DANTAS (1956), em Pernambuco, estando, atualmente, disseminado por todas as regiões canavieiras de São Paulo e demais Estados do Brasil.

E bem provável que a ausência de qualquer sintoma externo es pecifico tẹnha dificultado a Identificação e os estudos iniciais da doença, no Brasil (MATSUOKA, 1971a).

Até 1971, os trabalhos sugeriram que um virus estava, provavelmente, envolvido (SCHEXNAYDER, 1956; FORBES e LING, 1960; STEINDL; 1961; CARVALHO, 1963; GILLASPIE et alii, 1966; GALLI et alii, 1968; GILLASPIE, 1970/1971). A possível associação de um micoplasma com a moléstia (STEIB e 
TANTERA, 1970) ou um micoplasma mais um vírus (KHURANA, 1972) também foi su gerida, sem apresentar provas concretas. Mais tarde, PLAUSIC-BANJAC e MARA MOROSCH (1972), TEAKLE et alii (1973) e TEAKLE (1974) relataram a presença de corpos pleomórficos, lembrando "bactérias muito pequenas ou corpos parecidos a micoplasma e Rickttsia", no xilema de colmos maduros e doentes, mas não ẹ plantas sadias de cana-de-açúcar. CHEN et alii (1975), GILLASPIE et alii (1976a), RICAUD et alii (1976), DAMANN e DERRICK (1976) confirmaram que uma bactéria coréneforme estava associada com plantas de cana-de-açúcar infectadas com RS, mas não com plantas sadias.

Embora, até o presente momento, a maioria dos pesquisadores concorde que o agente é,provavelmente, uma bactéria, a natureza exata do or ganismo e seu tamanho permanecem controvertidos. Por exemplo, certos pesqui sadores, sugeriram como possíveis agentes, as bactérias causadoras de escal dadura (Xanthomonas albilineans) e da gomose (Xanthomonas vasculorum). Mas, a maior discrepāncia é com relação ao tamanho do organismo. A maioria dos pesquisadores citaram valores entre $0,12-0,5 \times 0,6-0,3 \mu \mathrm{m}$, embora relatos de Louisiana dimensionam valores entre 0,3-0,5 × 5,0-10,0 $\mathrm{mm}$ (GILLASPIE et alii, 1976a).

RICAUD et alii (1976) relataram que, de värias bactértas encontradas nos exsudatos de cana, exibindo sintomas de RS, a mais predominan te apresenta várias características daquelas citadas na literatura, embora nenhum septo tenha sido observado. Ela foi encontrada nos nós, nos internó dios de colmos afetados, nos tecidos abaixo do ponto de crescimento e nas folhas, indicando que não é um contaminante passivo e restrito aos ferimentos e cicatrizes das folhas. Enquanto isso, a bactéria não foi encontrada em tecidos de plantas sadias. Os exsudatos de colmos infectados com as 
doenças Estrias Cloróticas, Gomose e Escaldadura das Folhas que apresentaram sintomas de descolorações vasculares nodais, podendo serem confundidas com RS, revelaram porém, a presença de inúmeras bactérias diferentes daquela do RS em tamanho, morfologia e outras características. Portanto, sugestões de que $X$. vasculorum e $X$. albilineans estejam associadas com RS não po deriam ser substanciadas.

Recentemente, GILLASPIE et alii (1976a) citaram apenas uma evidência adicional de patogenicidade do provável agente causal do RS, mostrando que a maioria dos trabalhos tem apenas valor relativo, pela não comprovação do teste de patogenicidade, através do Postulado de Koch.

Com relação à disseminação do agente causal, MATSUOKA (1975) cita, em seu artigo, os meios através dos quais o RS é propagado; salientan do a sua importância, uma vez que a moléstia não causa sintoma externo característico, o que de certo modo contribui para sua propagação.

\subsection{Sintomas diagnōsticos e interferência de fatores na sua expressão}

Embora o RS possa causar na cultura da cana-de-açücar um as pecto prejudicial, com colmos atrofiados, plantas subdesenvolvidas e variações na altura das plantas no campo, nenhum desses sintomas externos é especifico da doença, sendo, em consequência, de pouco valor para a diagnose (STEINDL, 1961; GILLASPIE et alii, 1966; MATSUOKA, 1971a). Por isso, o RS foi por algum tempo considerado entre as doenças sem sintomas, até que foram descobertos os sintomas internos (HUGHES e STEINDL, 1955).

Na parte interna de colmos maduros e inoculados de algumas 
.9 .

variedades padrōes para RS aparecem sintomas, constituindo-se em pontuações, virgulas ou bastonetes rosados, amarelados ou avermelhados, correspon dendo às alterações ocorridas nos feixes vasculares da região nodal (HUGHES e STEINDL, 1955; STEINDL, 1961; CARVALHO, 1963 e GILLASPIE et alii, 1966). Tal coloração é devida ao acúmulo de substâncias gomosas nos vasos condutores (ARTSCHWAGER, 1960).

Um outro tipo de sintoma é o de nós imaturos, situados logo abaixo do meristema apical. Esses nós apresentam, internamente, uma colora ção levemente rósea, logo após o corte (HUGHES e STEINDL, 1955; SCHEXNAYDER, 1960; STEINDL, 1961; GILLASPIE et alii, 1966).

Em geral, os pesquisadores australianos preferem os sintomas de nós maduros, pois as descolorações em nös imaturos são considieradas menos seguras, por serem menos constantes, nem sempre visiveis e, frequentemen te, desaparecem na cultura adiantada (HUGHES, 1956/1960).

As descolorações nodais dependem das variedades (HUGHES $e$ STEINDL, 1955), mas, em gerai, pontos castanho-avermelhados mais escuros de vem ser menosprezados, pois são comuns às plantas sadias e doentes. HUGHES e STEINDL (1955), enfatizaram que sintomas devem ser encontrados, através de värios nós do colmo para a correta diagnose do RS. Segundo CARVALHO (1963), MATSUOKA (1971a), STEIB e CHILTON (1972), quando isso não ocorre, os sintomas podem ter outras causas, como, por exemplo, ataque de fungos.

A descoloração de feixes vasculares não è umà reação especifica do RS e ocorre com outras doenças tais como, Fusarioses, Podridão Vermelha, Mancha Vermelha da Bainha Foliar, Gomose, Escaldadura das Folhas e 
Estrias Cloróticas. As três primeiras, normalmente, causam uma descoloração ma1s escura do que RS e podem ser distinguldas, enquanto que as outras très doenças, embora da mesma cor, normalmente, apresentam sintomas mais pronunciados nos nós, extendendo-se aos 1nternódios. A descoloração, devido a essas três ültimas doenças, pode também ser encontrada nos nós ma1s imaturos do colmo, enquanto o RS, normalmente, é encontrado nos nós ma1s maduros da base do colmo (HUGHES e STEINDL, 1955). Essa descoloração vascular fol confirmada por TOKESHI et alii (1974).

RICAUD (1974), mencionou que, além da presença de outras doenças, vários outros fatores podem afetar a expressão dos sintomas, tals como, as características varieta1s, condiçōes climäticas e estado fisiológi co da planta. Por essas razões, os sintomas diagnósticos são completamente Inexatos sob certas condiçōes.

HUGHES e STEINDL (1955), citaram que o sintoma de RS varia com a Idade do colmo e condiçōes climáticas nos diferentes loca1s de plant10, enquanto que THOMPSON (1960) observou que os sintomas foram claramente visiveis, sob condiçōes de estufa; quando a àgua não fol fornecida para as plantas inoculadas com RS. Ma1s tarde. STEINDL (1961) e ROSSLER (1974) con firmaram a afırmação anterior, com variedades de cana submetidas aos efe1tos do RS a diferentes nive1s de 1rrigação.

Nos ensalas conduzidos com duas cultivares de capim-elefante (Pennisetum purpureum Schum] e um híbrido, MATSUOKA (1971b/1972a) mostrou que condiçôes favorávels à maturação precoce aumentaram a Intensidade e a expressão de sintoma de descoloração vascular devido à Infecção do RS em ca pim-elefante. 
A expressão sintomatológica, em plantas novas afetadas por RS, foi acentuada, após a aplicação de fertilizantes nitrogenados e em plan tas sombreadas. Observou, também, que não houve diferença entre plantas crescidas de toletes inoculados e àquelas naturalmente infectadas,com relação à expressão de sintomas (IRVINE, 1975).

RICAUD (1974) concluiu que o diagnóstico, sem conhecer a cau sa do RS, é muito difícil e só pode ser efetuado levando-se em consideração, todos os fatores que podem interferir na sua determinação.

Segundo TEAKLE (1974), a diagnose é frequentemente difícil, ou porque os sintomas não são claros, ou porque os sintomas resultantes do RS são parecidos aos de outras causas.

3.3. Diagnose através de testes biolōgicos, tēcnicas microscōpicas e serológicas

Devido às dificuldades de diagnose correta relacionadas aos vários fatores mencionados anteriormente, alguns pesquisadores têm ensaiado o método tradicional de inoculação em plantas indicadoras, para a diagnose correta de RS. HUGHES e STEINDL (1956) näo obtiveram èxito ao infectar tomate, Nicotiana glutinosa e beringela. Várias gramineas foram também testa das (HUGHES e STEINDL, 1956; STEINDL, 1957) e a infecção fol sucesso sem ex pressão de sintomas em milho, sorgo e 10 ervas daninhas, como verificado por reinoculąção na variedade de cana Q28.

Até recentemente, a melhor planta indicadora tem sido a própría cana-de-açúcar. Certas variedades são preferidas: Q28 (HUGHES e STE- 
INDL, 1955; STEINDL e TEAKLE, 1975), CP44-101 (GILLASPIE et alii, 1966), CO 421 (SINGH, 1969) \& Q28, CP36-105, CP44-101 e CO 421 (RICAUD, 1974).

MATSUOKA (1971b/1972a) encontrou que dois cultivares de capim-elefante e um híbrido, mostraram sintomas bem definidos em nós maduros quando infectados com RS.

TOKESHI et alii (1974) utilizaram em testes de patogenicidade plantas indicadoras de sintomas de RS como: milho doce, capim-elefante e cana-de-açūcar.

Mais recentemente, alguns pesquisadores têm usado técnicas mi croscópicas como meio de diagnose da doença em laboratório.

Uma pequena bactéria associada com o RS pode ser : detectada pela técnica de microscopia eletrônica constituindo-se num método rápido de identificação da doença (MARAMOROSCH et alii, 1973; TEAKLE et alii, 1973; WORLEY et alii, 1975; KAMIUNTEN e WAKIMOTO, 1976; BAILEY, 1976). Entretanto, essa técnica requer muitos equipamentos dispendiosos e especialmente operadores treinados (STEINDL, 1976b).

0 RS pode ser diagnosticado pelo exame de exsudatos do xilema, através de microscopia de contraste de fase, pela presença de uma bacté ria que està constantemente associada à doença (GILLASPIE et alii, 1973; TEAKLE et alii, 1975; STEINDL, 1976a; GILLASPIE et alii, 1976b). No entanto, essa técnica apresenta limitações quando aplicada para colmos imaturos, visto que as preparações dos tecidos tem poucas bactérias e dificulta a diagnose da doença (BAILEY, 1977). 
Técnicas serológicas foram largamente usadas no passado, para seleção de material propagativo e as tentativas, para obtenção de um anti soro para o agente do RS com cana-de-açūcar, têm falhado (STEINDL, 1961).

Recentemente, através da serologia, antisoros foram desenvol vidos para a bactéria associada ao RS. A falta de reação serológica entre antisoro-RS e a bactéría associada ao RS, em suco de cana-de-açúcar não con centrado, limita o sucesso do teste de microaglutinação, para diagnose. 0 método poderia ser usado para teste de resistência, por centrifugação do su co de cana, porém, esta operação limitaria o número de amostras analisadas. A técnica, baseada na microscopia eletrônica, foi relatada como suficientemente sensível para a diagnose de suco de cana não concentrado (DAMANN et alii, 1977), mas esta técnica não é suficientemente econômica para a diagno se do RS. Métodos, tal como da floculação com bentonita (BOZICEVICH et alii, 1963), podem ser bastante sensíveis e úteis, na seleção de plantas resistentes. Visto que as variedades suscetiveis ao RS contêm alto número de bactérias associadas (GILLASPIE et alii, 1976b), um método serológico poderia detectar somente aquelas variedades com alto nümero de bactérias (GILLASPIE, 1977). Portanto, a serologia não constitui num método ideal para seleção de cultivares visando resistència ao RS.

\subsection{Controle da doença}

O emprego de cultivares resistentes ou imunes não é, ainda, um método empregado como técnica usual de controle da doença, pois, pratica mente, todas as variedades comerciais do mundo são tolerantes ou suscetiveis. Apenas uma ou outra variedade apresenta uma tolerância satisfatória 
(ABBOTT et alii, 1967) tendo-se relato de uma única variedade que parece apresentar imunidade (WISMER e URATA, 1967). Para as variedades cultivadas em nosso meio, existe caréncia de dados concretos sobre o comportamento diante do RS (MATSUOKA, 1971a).

A obtenção de material de plantio sadio, pela prática do "roguing" que consiste em erradicar as plantas doentes nos viveiros, não tem aplicação no caso de RS, devido a ausência de sintomas externos de fácil identificação (HUGHES e STEINDL, 1955). Portanto, o material vegetativo sadio precisa ser obtido de outra forma. A técnica adotada é o tratamen to térmico com água quente ou com ar quente, embora o material assim obtido não seja totalmente sadio (MATSUOKA, 1971c/1972b).

Segundo RICAUD (1974), as seguintes doenças estão 'entre aque las que podem ser eliminadas pelo tratamento térmico: Estrias Cloróticas, Gomose, Escaldadura das Folhas e Carvão. Em muitos casos, onde a excessiva redução de produção é atribuida à presença do RS, o efeito pode ser devido à combinação de RS com outras doenças, se essas são levadas em consideração. Portanto, o uso do tratamento térmico, para deter os efeitos da doença RS, necessita de estudos mais cuidadosos.

Recentemente, STEIG e CIFUENTES (1976) relataram que o trata mento térmico, através do vapor úmido, pode ser um método adicional para controlar o RS. Esse novo método permite tratar a semente de cana-de-açúcar, sem afetar a germinação, num período de tempo reduzido para 4 horas a $53^{\circ} \mathrm{C}$.

O tratamento térmico de sementes de cana, através de água 
quente ou vapor úmido, apesar de ser útil e necessário, não apresenta eficiência total na prática, principalmente, devido às reinfestaçōes do RS, que se vêm observando logo no primeiro corte da cana, nas cultivares consideradas suscetiveis e ao elevado custo.

\subsection{Métodos de avaliação de doenças baseados na anatomia vascular}

Diante das dificuldades encontradas para diagnose e controle de doenças, alguns autores procuraram estudar a possível resistència do hos pedeiro a determinadas doenças, baseados na anatomia dos feixes vasculares.

PELTIER e SCHROEDER (1932) estudaram a anatomia de plantas resistentes e suscetíveis à Murcha Bacteriana de alfafa (Medicago sativa L.), causada por Corynebacterium insidiosum (Mc Cull.) Jens. Concluịram que as características morfológicas de ralzes de variedades resistentes inibiram o rápido desenvolvimento da bactéria e sua invasão nos tecidos vitais da plan ta. JONES (1934) não encontrou diferenças estruturais entre variedades resistentes e suscetíveis, mas observou que a bactéria, em variedades resistentes, limitou-se ao parênquima.vascular, sugerindo ser o fator de resistência à doença.

Mais tarde, CHO et alii (1973), trabalhando também com alfafa, observaram que as raizes e caule de plantas de alfafa de variedades resistentes à Murcha Bacteriana apresentaram menos feixes vasculares, elementos de vasos mais curtos e cortex mais espesso do que aqueles de plantas de variedades suscetíveis. Concluíram que tanto as barreiras morfológicas como as físico-químicas deveriam retardar e previnir a multiplicação e a difu são da bactéria nas variedades resistentes. 
.16 .

SAALTINK e DIMOND (1964), estudaram em tomate, a doença Murcha de fusarium, onde as plantas suscetiveis foram inoculadas com Fusarium oxysporum 6. lycopersici (Sacc.) Snyd. and Hans. Tais plantas mostraram sin tomas de murcha, regularmente, após 12 - 14 dias. Plantas, em estágios variados de doença, foram classificadas, de acordo com a sua severidade, em grau zero, para plantas sadias e grau 4, para as plantas mortas. Segmentos de caule de $1 \mathrm{~cm}$ de comprimento, dessas plantas, foram cortados desde o pri meiro internódio e a taxa de vazão de liquido, através desses segmentos, fol determinada pela ligação da extremidade superior do segmento a um tubo de vidro vertical, contendo uma coluna de água de $50 \mathrm{~cm}$, através de uma luva de borracha. A taxa de vazão foi determinada, por medição do tempo exigido, para um dado volume de água ou solução de tinta (safranina 0) passar através do segmento do caule. Os resultados mostraram que a vazão dé água fo1 muito mals rápida em segmentos de plantas de tomate sadias do que através daquelas infectadas com Fusarium.

Segundo LUDWIG (1952; WAGGONER e DIMOND (1954) e DIMOND (1955), a diferença na taxa de vazão entre plantas de tomate sadias e infeç tadas por Fusarium não tem sido explicada, pela quantidade de micélio, mas sim, pela presença de material granular obstruindo os vasos. WAGGONER e DI MOND (1955) explicam a redução de vazão, não só pela presença física do fun go, como também por produtos do fungo ou sua ação sobre os vasos. SAALTINK e DIMOND (1964) usaram solução de tinta nos experimentos e demonstraram que a redução na taxa de água estava correlacionada com o número de vasos em que o transporte é bloqueado.

ELGERSMA (1970) afirmou que a anatomia vascular, aparentemen 
te, influiu na resistência ao movimento de conídios de Ceratocystis ulmi, em olmo, por causa da presença de vasos estreitos e curtos das variedades resistentes à doença ("Duth elm disease").

Em testes conduzidos com tinta nanquim, para observar a conduta dos vasos contínuos, através dos nós de diferentes variedades de cana- de-açúcar testadas para resistência à Podridão Vermelha, causada por PhysaLospora tucumanensis, ATKINSON (1938) e ABBOTT e HUGHES (1961) concluiram que a anatomia vascular, aparentemente, influiu na resistência à doença: os conídios do patógeno não podem migrar desde a infecção inicial de internódios em clones resistentes como a CP29-116, que apresentam, principalmente, vasos descontínuos através dos nós.

A natureza da resistência da cana-de-açúcar no RS: não tem sị do estudada em detalhe, mas relatos preliminares indicam que ocorre pelo me nos três tipos de resistência. Baseado nisto, TEAKLE et alii (1975) investigaram a hipótese de que a anatomia vascular poderia estar envolvida na re sistência ao RS. O método de movimento de água e tinta nanquim, através de toletes de colmos de cana-de-açúcar, foi testado em 10 diferentes clones. A base de cada colmo foi cortada e examinada para verificar se não havia sintomas de RS e outras doenças. Toletes de $6,0 \mathrm{~cm}$, compreendendo um único nó e partes de internódios adjacentes, foram tomados da porção mediana de colmos e o diàmetro de cada tolete foi medido.

A vazão de água, através de cada tolete, foi determinada da seguinte maneira: uma extremidade do tolete foi ligada ao frasco de vácuo, através de uma ou mais Iuvas de borracha, enquanto que, na extremidade supe rior foi pipetada água destilada e estéril, ao mesmo tempo que uma pressão 
de väcuo de aproximadamente $27 \mathrm{~mm} / \mathrm{Hg}$ foi aplicada, através de uma bomba de vácuo. A taxa de vazão de água foi determinada em $\mathrm{ml} / \mathrm{minuto.}$

0 movimento de tinta nanquim foi testado de maneira semelhan te ao descrito acima, usando toletes com dois nós. Tinta nanquim foi pipetada sobre a extremidade superior do tolete introduzido no frasco de vácuo e a contagem do número de feixes vasculares descoloridos foi feita após 30 segundos, quando os internódios foram cortados tangencialmente, para mostrar mais claramente os feixes escurecidos.

Uma correlação positiva foi estabelecida entre resistência de cana ao RS e resistência ạo movimento de ägua e tinta nanquim, sugerindo que a anatomia vascular estaria envolvida. 0 agente causal pode ter maior dificuldade em mover-se através dos nós de cana-de-açúcar, imune e tolerante do que a suscetivel. Isto foi verificado pelo teste da tinta nanquim. 0 número médio de feixes vasculares carregando tinta nanquim, através dos toletes de duas variedades suscetiveis, foi maior do que para tres variedades tolerantes e imunes. Os autọres concluiram que a anatomia vascular, possivelmente, na forma de um pequeno nümero de vasos contínuos, passando através dos nós, pode ser um fator na resistência, imunidade e tolerância de clones ao RS (TEAKLE et alii, 1975).

Desse modo, a resistência baseada nas características morfológicas, tal como anatomia vascular, pode ser importante, por causa da sua estabilidade. CHO et alii (1973) relataram que variedades de aifafa com re sistência morfológica à C. insidiosum têm crescido, extensivamente, sobre vastas áreas dos EEUU e Canadá, por 20 anos, sem perder a resistência. 
RS assemelha-se à Murcha Bacteriana da alfafa, em que o patógeno é restrito aos feixes vasculares e ao parênquima adjacente (TEAKLE et alii, 1973). 


\section{MATERIAL E METODOS}

\subsection{Método de avaliação do RS}

0 método empregado por TEAKLE et alii (1975), para medir a vazāo de água e tinta nanquim, através de colmos de cana-de-açúcar, foi a base da metodologia empregada no trabalho.

Para a montagem do equipamento utilizado no método de vazão, inicialmente, fol construído o molde de aço, com o pino central em diâmetros variáveis, para a fabricação de luvas de borracha latex, conforme os Apêndices 1 e 2.

Toletes de colmos de $8 \mathrm{~cm}$ de comprimento, compreendendo um único nö e partes de internódios adjacentes, foram cortados próximos à base do colmo e o diâmetro de cada tolete do colmo foi medido em $\mathrm{cm}$. Em seguida, foram reavivados com o instrumento de corte de cana e luvas de borracha inseridas em ambas as extremidades, sendo que a luva correspondente a uma extremidade do colmo foi encaixada diretamente no frasco de vácuo, através de 
um intermediário metálico. Uma pressão de vácuo de $30 \mathrm{~mm}$ de $\mathrm{Hg}$ foi aplicę da ao equipamento por meio de uma bomba de vácuo, ao mesmo tempo que colocou-se água destilada na luva da outra extremidade do colmo de cana-de-açúcar, de acordo com a Figura 1 e Apêndice 3.

A vazão de água, passando através dos colmos, foi determinada medindo-se o volume de água coletado nos tubos de cultura colocados dentro dos frascos de vácuo, durante o tempo de 15 minutos, como mostra a Figu ra 2 e os Apêndices 4,5 e 6 .

Concomitantemente às determinações, os mesmos colmos foram cortados longitudinalmente e examinados internamente na região nodal para verificar se aqueles, com sintomas tipicos de RS e de outras doenças vasculares, estavam correlacionados com a variação da vazão de água nós colmos de cana-de-açúcar. Por outro lado, consideramos o isolamento de bactérias de colmos de cana-de-açúcar com sintomas de vasos descoloridos (RS), executado por SUDO (1976), como um outro meio de comprovar a citada correlação.

De maneira semelhante à descrita acima e, aproveitando os mesmos colmos, foram feitas determinações de vazão com tinta nanquim diluida na proporção 1:10, mas num período de tempo menor, ou seja, 2 a 3 minutos, interrompido quando ocorria o início do gotejamento de tinta no tubo de cultura:

A habilidade da tinta nanquim em mover-se através dos nós foi assegurada baseando-se no número de vasos funcionais do xilema enegreci dos. Para melhor visualização, o internódio correspondente à extremidade do colmo, encaixado no frasco de väcuo, foi cortado transversalmente, e feita 
.22

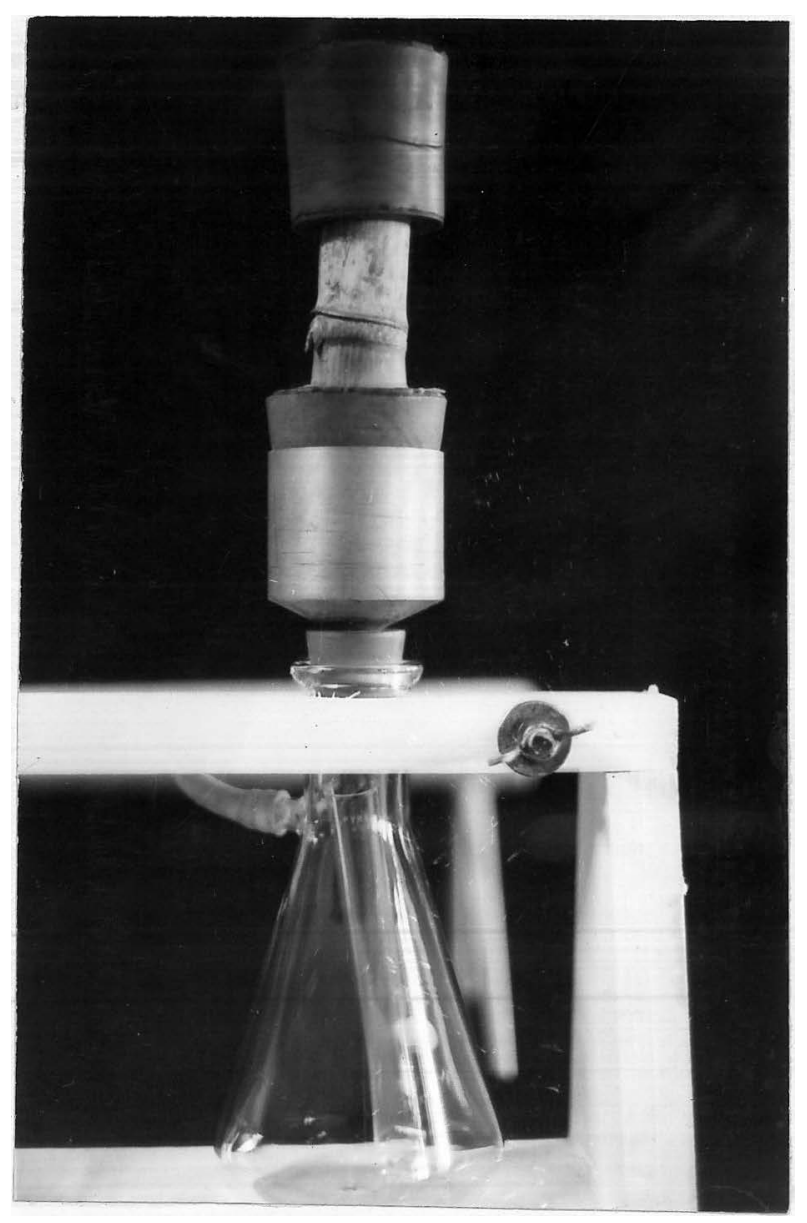

Figura 1. Conjunto extrator de àgua de colmos de cana-de-açúcar. 
.23

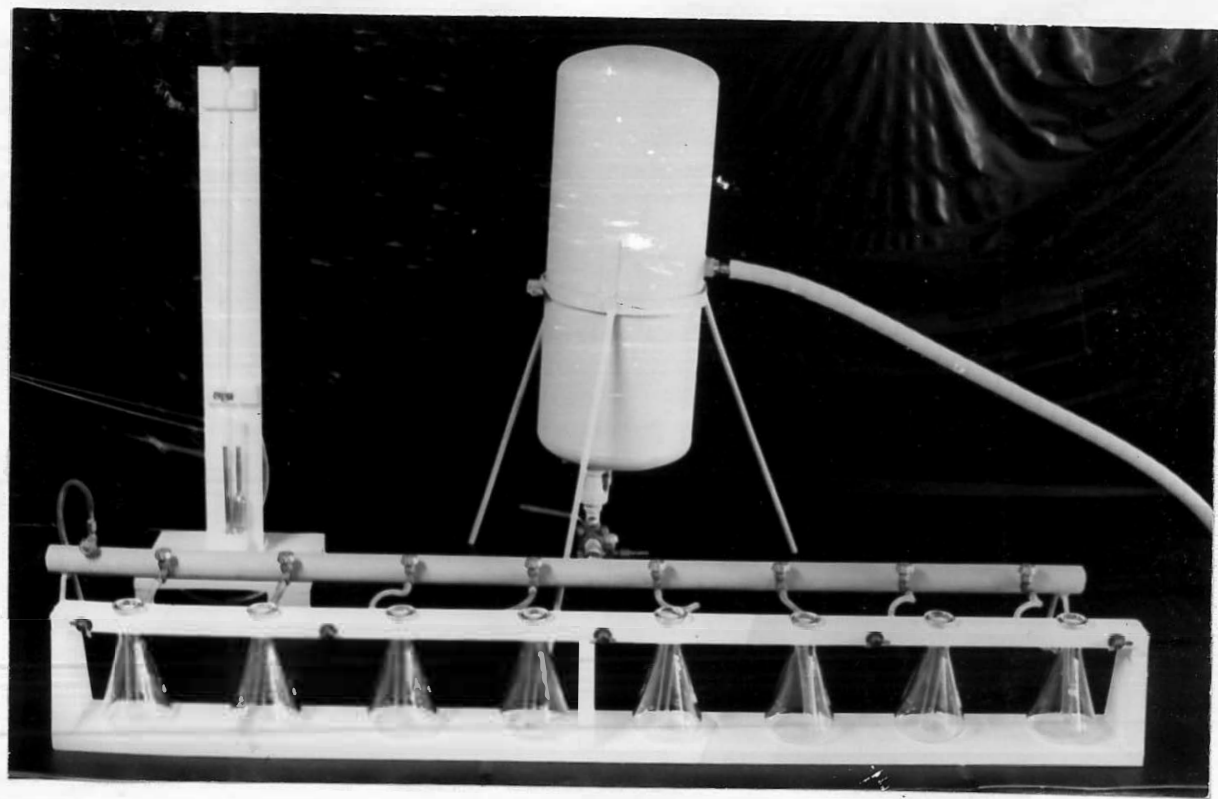

Figura 2. Medidor de vazão de água em colmos de cana-de-açúcar. 
.24.

a contagem do número de vasos funcionais, em microscópio esteroscópio, com aumento de 130 vêzes.

Essencialmente, foram introduzidas as seguintes modificações no método descrito por TEAKLE et alii (1975):

a. testes em cultivares tratadas termicamente (sadias) e ino culadas com caldo bruto (doentes);

b. testes com 8 frascos de vácuo dispostos em série;

c. uso de funil metálico como intermediário;

d. toletes fixados ao $4^{8}$ ou $5^{8}$ nó da base do colmo;

e. comprimento maior do tolete do colmo;

f. pressão de vácuo constante.

A Figura 3 mostra o vacuômetro de mercúrio em $U$, de alta pre cisão e baixo custo, utilizado no trabalho de pesquisa. Consta de duas has tes de vidro, sendo uma delas mais longa e ligada à fonte de vä́cuo e, a outra mantida à pressão atmosférica. Desse modo, foi possível controlar a pressão de vácuo constante e desejada.

Determinou-se a variação de vazão, nas cultivares de cana-de -açúcar tratadas termicamente (SILVA, 1976), inoculadas com caldo bruto extraído de plantas infectadas pelo RS e inoculadas com cultura pura de X. al bilineans, sendo as amostras tomadas ao acaso de 10 - 20 colmos/tratamento. Os colmos usados nos testes foram fornecidos pelas Estações Experimentais da COPERSUCAR, Piracicaba-SP e PLANALSUCAR, Araras-SP.

Durante as avaliações de vazão, estudaram-se os efeitos dos seguintes fatores: 
.25 .

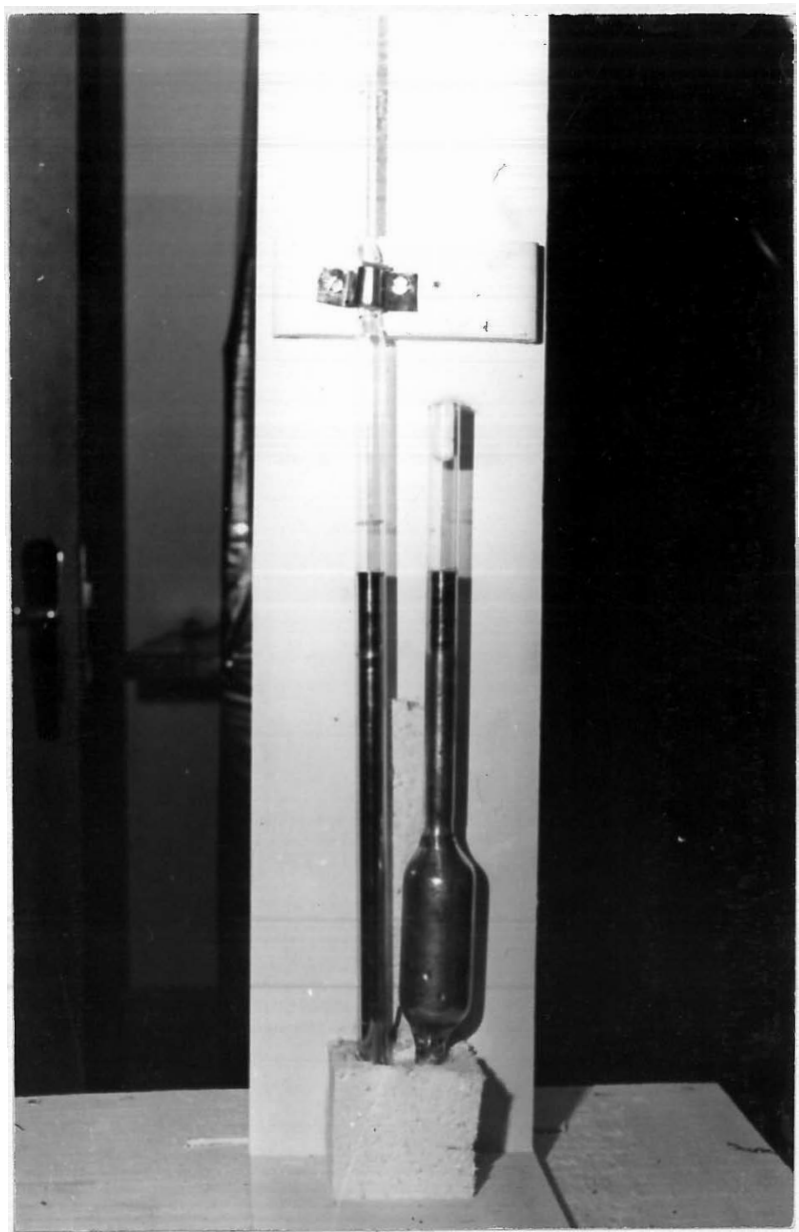

Figura 3. Vacuômetro de mercür1o ut1l1zado no mëtodo de vazao. 
a. pressão de vácuo de 30 a $70 \mathrm{~mm}$ de $\mathrm{Hg}$;

b. sentido do colmo - normal e invertido;

c. localização do nó no colmo: basal, média e apical;

d. diâmetro do colmo de 2,5 a $5,0 \mathrm{~cm}$;

e. armazenamento do colmo de 0 a 5 dias;

f. outras doenças vasculares;

g. colmos com broca (Diatraea saccharalis);

h. idade do colmo;

i. distribuição da doença dentro da touceira.

\subsection{Isolamentos}

Em seguida às determinações de vazão, conduziu-se o isolamen to de agentes causais de doenças vasculares, frequentemente presentes nos colmos de cana-de-açūcar, e que poderiam interferir na avaliação do RS.

\subsubsection{Isolamento de Fusarium moniliforme Sheidon no colmo}

A partir do material utilizado na determinação da vazão de água, foi tomada amostra de 5 colmos/tratamento de cada cultivar de cana-de -açücar, sem broca e sem rachaduras, para fins de isolamento de Fusarium.

No laboratório, tres (3) toletes de $2,0 \mathrm{~cm}$ de comprimento, compreendendo um único nó, foram cortados ao longo de cada colmo e mergulha dos em hipoclorito de sódio com 5\% de Cl ativo (Qboa), durante 15 minutos. A seguir, os toletes foram descascados e flambados em fogo direto, para desinfecção externa dos toletes. Posteriormente, retirou-se de cada tolete um disco de tecido de aproximadamente $2 \mathrm{~mm}$ de espessura,e plaqueou-se em meio 
de cultura (RB-O) de Martin (TUITE, 1969). As placas de Petri foram incuba das à temperatura de 28 a $30^{\circ} \mathrm{C}$, durante 48 horas, e, finalmente, procedeu-se a identificação para a presença de Fusaruum, através do exame, em lâmina, ao microscópio binocular (BARNETT e HUNTER, 1972).

\subsubsection{Escaldadura das folhas (Xanthomonas albilineans) (ASHBY) DOW SON}

A Escaldadura das Folhas é considerada uma doença que apresenta sintomas internos no colmo, muito semelhantes aos do RS, que, muitas vêzes, chega a causar confusão. Diante disso, tornou-se importante testar materiais tratados termicamente e inoculados com LSD e avaliar a doença, através do método de vazão de água.

A bactéria $X$. albilineans foi isolada em meio de cultura de Wilbrink agar (TUITE, 1969) e diagnosticada em reações serológicas, através do método do anel (CAMPBELL et alii, 1970), modificado por MASSUDA (não publicado), partindo-se de sintomas típicos de Escaldadura, na forma de vírgu las e bastonetes, observados na régião nodal dos colmos de cana-de-açücar.

\subsection{Medidas de diâmetro do lume dos vasos do xilema}

Sabendo-se que as cultivares de cana-de-açücar apresentam com portamentos diferentes com relação ao RS, procurou-se medio os diâmetros do lume dos vasos do xilema de duas cultivares de cana: 'IAC 52/326' e 'NA56-79', com o objetivo de verificar se a anatomia vascular estava envolvida na resistência ao RS. 
Dessa maneira, tomaram-se 6 colmos de cada cultivar, com diâmetros mais ou menos constantes e, a partir do internódio localizado en tre o nó número 4 ou 5 foram feitos cortes de tecidos transversais ao colmo, de 10 a $15 \mu$ de espessura, através do Micrótomo manual de Nachet. Em segui da, procedeu-se a medida do diâmetro de 100 vasos por colmo de cana-de-açúcar, ao microscópico binocular, com aumento de $125 \times$. 
.29 .

5. RESULTADOS

Os resultados do trabalho são apresentados na seguinte sequência: (a) resultados dos fatores que interferem na avaliação do RS; (b) resultados de isolamentos de agentes de doenças vasculares; (c) "resultados de aplicação do método de vazão de água em colmos ve cana-de-açúcar para avaliar o RS e, (d) resultados de medidas do diâmetro da luz dos vasos do xilema.

5.1. Fatores que interferem na avaliação do RS

\subsubsection{Pressão de vācuo}

A Tabela 1, mostra o efeito de diferentes pressões de väcuo, testadas na determinação da vazão média de água, em duas cultivares de cana, submetidas à-inoculação com RS e tratadas termicamente. 
Tabela 1. Efeito da pressão de vácuo na vazão média de colmos de ciana-de-a çücar, tratados termicamente e inoculados com caldo bruto (RS).

\begin{tabular}{|c|c|c|c|c|}
\hline \multirow{4}{*}{$\begin{array}{c}\text { Pressão } \\
\text { de } \\
\text { văcuo } \\
\text { (mm } \mathrm{Hg} \text { ] }\end{array}$} & \multicolumn{4}{|c|}{ Vazão média de 20 colmos/tratamento em $\mathrm{ml} / 100^{\prime}$} \\
\hline & \multicolumn{4}{|c|}{ Cultivares } \\
\hline & \multicolumn{2}{|c|}{ 'IAC52/326' } & \multicolumn{2}{|c|}{ 'CP45-184' } \\
\hline & Caldo bruto & Tratado & Caldo bruto & Tratado \\
\hline 30 & 15,86 & 54,12 & 28,62 & 110,34 \\
\hline 50 & 18,70 & 36,75 & - & - \\
\hline 70 & 244,50 & 293,50 & 152,50 & 256,69 \\
\hline
\end{tabular}

Pelos resultados apresentados na Tabela 1 , verifica-se que o aumento de pressão de väcuo determinou o aumento considerável na vazão média para ambos os tratamentos das duas cultivares, enquanto que 'a diferença de vazão entre os tratamentos foi menor para a cultivar 'IAC52/326'.

\subsubsection{Sentido do colmo}

Os resultados da Tabela 2, referem-se às determinações de vạ zão média dentro dos mesmos colmos e em colmos diferentes para os sentidos normal e inverso ao da subida de seiva bruta no colmo de cana-de-açúcar, na cultivar 'NA56-79'. 
Tabela 2. Efeito do sentido do colmo na vazão média de água em colmos de ca na-de-açúcar, tratados termicamente, cultivar 'NA56-79'.

\begin{tabular}{|c|c|c|c|c|c|c|c|}
\hline \multirow{3}{*}{$\begin{array}{l}\text { Determi- } \\
\text { nação } \\
\text { de } \\
\text { vazäo }\end{array}$} & \multicolumn{7}{|c|}{$\begin{array}{c}\text { Vazão médía de } 12 \text { colmos/tratamento em ml/100', à } \\
\text { Pressão de vácuo de } 30 \mathrm{~mm} \mathrm{Hg}\end{array}$} \\
\hline & \multicolumn{4}{|c|}{18 LOTE } & \multicolumn{2}{|c|}{$2^{\circ}$ LOTE } & \multirow[b]{2}{*}{$\begin{array}{l}\text { Sentido } \\
\text { Normal }\end{array}$} \\
\hline & 18 & $\begin{array}{l}\text { Sentido } \\
\text { Normal }\end{array}$ & $2^{\circ}$ & $\begin{array}{l}\text { Sentido } \\
\text { Inverso }\end{array}$ & $\begin{array}{l}1^{\circ} \text { Sentido } \\
\text { Inverso }\end{array}$ & $2^{\circ}$ & \\
\hline No mesmos & & 155,83 & & 124,16 & 153,34 & & 130,00 \\
\hline \multirow[t]{3}{*}{ colmos } & & 132,50 & & 100,83 & 110,83 & & 98,34 \\
\hline & & 144,16 & & 92,50 & 135,94 & & 124,14 \\
\hline & & 160,83 & & 115,83 & 145,00 & & 105,00 \\
\hline Média & & 148,33 & & 108,33 & 136,27 & & 114,37 \\
\hline Em colmos & & 224,00 & & 174,00 & 150,00 & & 200,00 \\
\hline diferentes & & 213,00 & & 139,00 & 132,00 & & 194,00 \\
\hline Média & & 218,50 & & 156,50 & 141,00 & & 197,00 \\
\hline
\end{tabular}

Pela Tabela 2, verificam-se que os resultados de vazão média de água, correspondentes as determinaçöes dentro dos mesmos colmos, foram praticamente 1guais, 1sto é, o $2^{\circ}$ sentido sempre apresentou queda de vazāo em ambos os lotes. Porém, quando as determinaçōes foram feitas em colmos diferentes, o sentido normal mostrou a vazäo média maior que o sentido inverso, nos dois lotes. Por outro lado, a vazão média, dentro dos mesmos col mos, decresceu gradualmente com o tempo. 
5.1.3. Localização dos nōs no colmo

As Tabelas 3 e 4 , mostram os resultados correspondentes às determinaçōes de vazão média de água, em diferentes posições tomadas no col mo de trés cultivares de cana tratadas termicamente, e inoculadas com caldo bruto (RS).

Tabela 3. Avaliação de vazão média em diferentes nós do mesmo colmo de cana -de-açúcar, da cultivar 'CP45-184', tratado termicamente e inoculado com RS.

\begin{tabular}{|c|c|c|c|c|c|c|}
\hline \multirow{4}{*}{$\begin{array}{l}\text { Touceira } \\
n^{8}\end{array}$} & \multicolumn{6}{|c|}{$\begin{array}{l}\text { Vazão média de cada posição de touceiras com } 6 \text { a } 10 \\
\text { colmos em ml/100; à pressão de vácuo de } 30 \mathrm{~mm} \mathrm{Hg}\end{array}$} \\
\hline & \multicolumn{3}{|c|}{ Caldo bruto } & \multicolumn{3}{|c|}{ Tratado } \\
\hline & \multicolumn{3}{|c|}{ NÓ } & \multicolumn{3}{|c|}{ NO } \\
\hline & $A$ & $B$ & C & A & $B$ & C \\
\hline 1 & 22,09 & 27,09 & 40,01 & 128,72 & 150,08 & 130,72 \\
\hline 2 & 42,52 & 47,52 & 75,03 & 112,27 & 136,74 & 141,18 \\
\hline 3 & 21,26 & 30,01 & 40,85 & 90,04 & 135,07 & 130,90 \\
\hline Média & $28,62 a$ & $34,87 a$ & $51,96 a$ & $111,72 b$ & $140,63 b$ & $134,26 b$ \\
\hline C.V. $(\%)$ & 62,50 & 50,90 & 49,95 & 38,82 & 33,34 & 41,73 \\
\hline
\end{tabular}


Tabela 4. Avaliação de vazão média, em duas diferentes posições do mesmo colmo de cana-de-açücar, tratado termicamente e inoculado com RS.

\begin{tabular}{|c|c|c|c|c|c|c|}
\hline \multirow{5}{*}{$\begin{array}{c}\text { Tratamentos } \\
\text { dos } \\
\text { colmos }\end{array}$} & \multicolumn{6}{|c|}{$\begin{array}{c}\text { Vazão média de } 16 \text { colmos de cada posição em ml/100', à } \\
\text { pressão de vácuo de } 30 \mathrm{~mm} \mathrm{Hg} \text {. }\end{array}$} \\
\hline & \multicolumn{6}{|c|}{ Cultivares } \\
\hline & \multicolumn{2}{|c|}{ "СР 45-184' } & \multicolumn{2}{|c|}{ "CB45-3' } & \multicolumn{2}{|c|}{ 'CP51-22' } \\
\hline & \multicolumn{2}{|c|}{ NO } & \multicolumn{2}{|c|}{ NO } & \multicolumn{2}{|c|}{ Nó } \\
\hline & $A$ & $B$ & $A$ & $B$ & $A$ & $B$ \\
\hline c. bruto & $28,63 a$ & $34,88 a$ & $13,20 a$ & $22,10 a$ & $5,40 a$ & $5,53 a$ \\
\hline T. térmico & $111,72 b$ & $141,74 b$ & $16,34 a$ & $42,67 b$ & $4,47 a$ & $7,37 a$ \\
\hline C.V. $(\%)$ & 62,50 & 50,90 & 87,67 & 41,77 & 108,49 & 53,56 \\
\hline C. bruto & $28,63 a$ & $34,88 a$ & $13,20 a$ & $22,10 a$ & $5,40 a$ & $5,53 a$ \\
\hline T. térmico & $111,72 b$ & $141,74 b$ & $16,34 a$ & $42,67 b$ & $4,47 a$ & $7,37 a$ \\
\hline C.V. $(\%)$ & 38,82 & 33,34 & 90,45 & 40,70 & 103,75 & 49,65 \\
\hline
\end{tabular}

$A=$ NÓ nümero 4 ou $5 ; B=$ NÓ número 8 ou 9.

Dentro de cultivar, as médiàs com letras iguais não diferem, estatisticamen te.

Verifica-se pela Tabela 3, que fazendo-se comparaçöes dentro de cada posição, a análise estatística pelo Teste "t", mostrou que o caldo bruto diferiu, significativamente, do tratamento térmico, ao nível de $1 \%$, ao passo que as comparações, entre as posições dentro de tratamento, não mostraram diferenças significativas até mesmo pelo Teste de Tukey, embora exista uma ligeira tendência em aumentar a vazão de água da base do colmo para o seu ápice. 
A anālise de variància dos dados da Tabela 4 mostrou que a cultivar 'CP45-184' apresentou diferenças altamente significativas entre os tratamentos, dentro de posição, ao nível de $1 \%$ através do Teste "t", ao pas so que, entre as posiçães dentro de tratamento, não houve diferenças significativas. Por outro lado, a cultivar 'CB45-3' mostrou diferenças significativas, ao nível de $1 \%$, entre as posições dentro do tratamento térmico e entre os tratamentos dentro da posição 8 , enquanto que a cultivar 'CP51-22' bão diferiu, estatisticamente, em nenhum dos casos, embora existisse tendēn cia em aumentar a vazão da posição $A$ para $B$ e entre os tratamentos considerados.

\subsubsection{Armazenamento dos colmos}

Na Tabela 5, observam-se os dados de vazão média de ägua, re ferentes às determinações, logo após a colheita e 24 horas de armazenamento de duas cultivares de cana-de-açúcar, submetidas ao tratamento térmico e inoculadas com RS.

Pela Tabela 5, observou-se que houve uma queda brusca de vazão para ambas as cultivares, quando os colmos foram armazenados por 24 horas. Contudo, os tratamentos continuaram a diferir, estatisticamente, ao nível de $1 \%$, pelo Teste "t", embora as diferenças não fossem tão evidentes como aquelas verificadas na determinação após colheita. A cultivar 'CP45-184' foi mais sensivel ao armazenamento, pois mostrou uma vazão média menor que a cultivar 'IAC52/326', após 24 horas de armazenamento. 
Tabela 5. Efeito do armazenamento na vazão média de colmos de cana-de-açúcar, tratados termicamente e inoculados com caldo bruto (RS: .

\begin{tabular}{|c|c|c|c|c|}
\hline \multirow{4}{*}{$\begin{array}{l}\text { Determinação } \\
\text { de } \\
\text { vazão }\end{array}$} & \multicolumn{4}{|c|}{$\begin{array}{c}\text { Vazão média de } 20 \text { colmos/tratamento em ml/100: } \\
\text { à pressão de vácuo de } 30 \mathrm{~mm} \mathrm{Hg}\end{array}$} \\
\hline & \multicolumn{4}{|c|}{ Cultivares } \\
\hline & \multicolumn{2}{|c|}{ 'IAC52/326' } & \multicolumn{2}{|c|}{ 'CP45-184' } \\
\hline & Caldo bruto & Tratado & Caldo bruto & Tratado \\
\hline Após colheita & $15,97 a$ & $54,54 b$ & $28,62 a$ & $111,72 b$ \\
\hline C.V. $(\%)$ & 63,83 & 55,56 & 62,50 & 38,82 \\
\hline $\begin{array}{c}24 \text { horas após } \\
\text { colheita }\end{array}$ & $14,49 a$ & $26,52 b$ & $5,93 a$ & $13,52 b$ \\
\hline C.V. $(\%)$ & 88,00 & 81,34 & 65,37 & 87,33 \\
\hline
\end{tabular}

- Dentro de cultivar, as médias com letras iguais não diferem, estatistica mente.

5.1.5. Correlação positiva entre a vazão e o número de vasos funcio nais do xilemá

Nas Tabelas 6 e 7, são apresentados os resultados correspondentes às determinações de vazão de água, número de vasos funcionais do xilema e diâmetro do colmo para duas cultivares de cana, submetidas ao armaze namento, considerando duas posições do nó nos mesmos colmos, tratados termi camente e inoculados com RS. 
Tabela 6. Efeltos do posiçajo do nó do mesmo colmo e do armazenemento na vazäo de égue e o número de vasos funclonals do xilema, en canas tratadas tamicamente a inoculados com caluo bruto (RS), cultivar 'CB45-3'.

\begin{tabular}{|c|c|c|c|c|c|c|c|c|c|c|c|c|}
\hline \multirow{4}{*}{$\begin{array}{l}\text { Daterminaçäo } \\
\text { de } \\
\text { vazäo }\end{array}$} & \multicolumn{12}{|c|}{ Vazäo médla de $10 \mathrm{colmos} /$ trataniento em $\mathrm{ml} / 100 \%$ à pressajo de vácuo de $30 \mathrm{~mm} \mathrm{Hg}$} \\
\hline & \multicolumn{6}{|c|}{ Caldo Oruto (RS) } & \multicolumn{6}{|c|}{ Trotamento tërnico } \\
\hline & \multicolumn{3}{|c|}{$A$} & \multicolumn{3}{|c|}{8} & \multicolumn{3}{|c|}{ A } & \multicolumn{3}{|c|}{8} \\
\hline & $\begin{array}{l}0 \\
\mathrm{~cm}\end{array}$ & Vazöo & VF & $\begin{array}{c}0 \\
\mathrm{~cm}\end{array}$ & Vazào & VF & $\begin{array}{c}0 \\
\mathrm{~cm}\end{array}$ & Vazäo & VF & $\begin{array}{c}0 \\
\mathrm{~cm}\end{array}$ & Vazäo & VF \\
\hline \multirow{10}{*}{ Após colhe1ta } & 2.1 & 6.67 & 8 & 2.0 & 13.34 & 30 & 2,2 & 46,67 & 59 & 2.5 & 43.34 & 49 \\
\hline & 2.5 & 6.67 & 10 & 2,4 & 10.00 & 19 & 2.5 & 6.67 & 22 & 2.8 & 86.67 & 71 \\
\hline & 2,8 & 10,00 & 12 & 2.5 & 19,90 & 21 & 2,6 & 30.00 & 60 & 2.6 & 40.00 & 105 \\
\hline & 2.8 & 6.67 & 15 & 2.6 & 20.00 & 27 & 2.6 & 23,34 & 38 & 2,6 & 60.00 & 79 \\
\hline & 2.8 & 26.67 & 25 & 2.7 & 10.00 & 89 & 2,8 & 3,34 & 29 & 2.6 & 20.00 & 49 \\
\hline & 2.9 & 13,34 & 18 & 2,7 & 23.34 & 110 & 2,8 & 3,34 & 16 & 2,7 & 20.00 & 36 \\
\hline & 2.9 & 2.00 & 15 & 2.7 & 23.34 & 35 & 2,8 & 3,34 & 50 & 2.9 & 30.00 & 62 \\
\hline & 2.9 & 40,00 & 21 & 2.8 & 33,34 & 14 & 2.9 & 13.34 & 32 & 2.9 & 43.34 & 73 \\
\hline & 2.8 & 8,67 & 20 & 2.8 & 33,34 & 105 & 3.0 & 26.67 & 59 & 3.0 & 36.67 & 73 \\
\hline & 3.0 & 13,34 & 15 & 2.9 & 33.34 & 38 & 3,1 & 6.67 & 18 & 3,0 & 43.34 & 79 \\
\hline \multirow[t]{5}{*}{ Módia } & 2.7 & 13,200 & 16 & 2.6 & 22.000 & 49 & 2.7 & 16,340 & 38 & 2.7 & $40,34 b$ & 68 \\
\hline & 2.7 & 1.34 & 93 & 2,5 & 3,34 & 16 & 2.0 & 16.67 & 37 & 2,2 & 6.67 & 43 \\
\hline & $\therefore, 8$ & 20.22 & $1 \approx$ & 2.5 & 2.34 & 23 & 2.5 & 10.00 & $2 \varepsilon$ & 2.4 & $\varepsilon . \varepsilon ?$ & 25 \\
\hline & 2,8 & 11,34 & 38 & 2.6 & 18,87 & 10 & 2.8 & 33,34 & 75 & 2.7 & 3,34 & 53 \\
\hline & 2.8 & 2.00 & 3 & 2.7 & 10.00 & 15 & 2.6 & 13,34 & 65 & 2.8 & 36.67 & 85 \\
\hline \multirow{6}{*}{$\begin{array}{l}120 \text { horas aposs } \\
\text { colneito }\end{array}$} & 2,8 & 8.67 & 13 & 2.7 & 2.00 & .5 & 2.7 & 6.67 & 48 & 2.8 & 26.67 & 60 \\
\hline & 2.9 & 6.00 & 19 & 2.8 & 6,67 & 5 & 2,9 & 10,00 & 64 & 2.8 & 33.34 & 48 \\
\hline & 3,0 & $10 ; 00$ & 3 & 2.8 & 10,00 & 19 & 2.9 & 3.00 & 40 & 2.8 & 100,00 & 118 \\
\hline & 3,0 & 8,00 & $\mathbf{5}$ & 2.8 & 22,34 & 15 & 2.9 & 40,00 & 64 & 2.8 & 33,34 & 61 \\
\hline & 3.0 & 2.67 & 8 & 2.9 & 4.67 & 9 & 2,9 & 33,34 & 101 & 2,9 & 53,34 & 82 \\
\hline & 3.1 & 20,00 & 27 & 3,0 & 66,67 & 44 & 3.0 & 66.67 & 85 & 3.0 & 13,34 & 63 \\
\hline nad10 & 2,9 & 8.800 & 14 & 2.7 & 14.770 & 16 & 2.7 & 23,300 & 60 & 2.7 & 31.340 & 64 \\
\hline
\end{tabular}

A - nimero 4 ou 5,8 . NO nümero 8 ou 9,0 . O1ämetro do colmo, VF . Número de Vasos Funcionals. Dentro de trata mento, as médlas das posiçōes $A$ e $\theta$ com letras 1quals nảo difersm. estat1st1camente.

$$
\text { C.V.(3) }{ }_{\text {tratemento }}=68.73_{1} \quad C . V_{0}(8)_{\text {pos } 1 \text { çäo }}=70.74
$$


Tabela 7. Efaltos da posiçäo do nö do messma colmo e do armazonamento no vazào médla de águo e o nümero de vasos iuncionais do $\times 1$ lema, em canas tratadas termicamente a inuculadas com calio bruto (RS), cultivor 'CP51-22'.

\begin{tabular}{|c|c|c|c|c|c|c|c|c|c|c|c|c|}
\hline \multirow{4}{*}{$\begin{array}{c}\text { Dotermi naçäo } \\
\text { de } \\
\text { vazào }\end{array}$} & & äo mëd1 & de 1 & 1 mos & retamen & $\mathrm{em} n$ & $0 \cdot \dot{a}$ & ssäo de & yo $d e$ & $\mathrm{~mm} \mathrm{He}$ & & \\
\hline & \multicolumn{6}{|c|}{ Caldo Bruto (RS) } & \multicolumn{6}{|c|}{ Tratamento térm1co } \\
\hline & \multicolumn{3}{|c|}{ A } & \multicolumn{3}{|c|}{8} & \multicolumn{3}{|c|}{ A } & \multicolumn{3}{|c|}{8} \\
\hline & $\begin{array}{r}0 \\
\mathrm{~cm}\end{array}$ & Vazäo & VF & $\begin{array}{r}\mathrm{D} \\
\mathrm{cm}\end{array}$ & Vazào & VF & $\mathrm{cm}$ & Vazäo & VF & $\mathrm{D}$ & Vazäo & VF \\
\hline \multirow{10}{*}{ Aposs colhe1to } & 2.5 & 1,34 & 16 & 2.3 & 2.00 & 12 & 2.5 & 3.34 & 45 & 2.3 & 5,34 & 35 \\
\hline & 2.5 & 1,34 & 7 & 2.3 & 3,34 & 5 & 2,5 & 1.34 & 5 & 2.3 & 5.34 & 37 \\
\hline & 2.7 & 9.34 & 3 & 2.5 & 6.67 & 35 & 2.7 & 1.34 & 5 & 2.5 & 8.67 & 28 \\
\hline & 2.9 & 1.34 & 5 & 2.8 & 10,00 & 11 & 2,9 & 3.34 & 59 & 2.8 & 6.67 & 63 \\
\hline & 3,0 & 2.00 & 8 & 2.7 & 6.00 & 10 & 3.0 & 2.00 & 10 & 2.9 & 4.00 & 28 \\
\hline & 3,0 & 10,00 & 10 & 3.0 & 6.67 & 8 & 3,1 & 5,34 & 25 & 3,0 & 12.00 & 72 \\
\hline & 3.1 & 2.00 & 5 & 3.0 & 4,67 & 6 & 3,4 & 6.67 & 38 & 3,0 & 4,34 & 30 \\
\hline & 3.4 & 1,34 & 5 & 3.2 & 3,34 & 10 & 3.4 & 3,34 & 52 & 3.2 & 5,34 & 72 \\
\hline & 3,5 & 6.67 & 5 & 3,3 & 10,00 & 13 & 3,5 & 16,67 & 96 & 3,3 & 6.67 & 38 \\
\hline & 3.5 & 1,34 & 5 & 3,4 & 2.00 & 6 & 3.5 & 1,34 & 20 & 3,4 & 15,34 & 82 \\
\hline \multirow[t]{5}{*}{ midie } & 3,0 & 2.870 & 7 & 2.9 & 5.470 & 12 & 3.1 & 4.470 & 36 & $2.9^{\circ}$ & 7,370 & 49 \\
\hline & 2,7 & 6.67 & 5 & $\cdot 2.6$ & 4.00 & 6 & 3,0 & 2.00 & 7 & 2,9 & 4.67 & 15 \\
\hline & 2,8 & 3,34 & 3 & 2.7 & 4.67 & 6 & 3.0 & 2.00. & 13 & 2,9 & 7.34 & 9 \\
\hline & 9,0 & 1,34 & 3 & 2.8 & 5,34 & 5 & 3.1 & 2.00 & 8 & 2.8 & 4.87 & 13 \\
\hline & 3.0 & 3.34 & 2 & 2.8 & 3,34 & 4 & 3,1 & 2,00 & 10 & 2.9 & 6.67 & 21 \\
\hline \multirow{6}{*}{$\begin{array}{l}120 \text { horas opós } \\
\text { colhe1to }\end{array}$} & 3,0 & 0.67 & 2 & 2.8 & 0.67 & 5 & 3.1 & 7.34 & 17 & 3.0 & 5.34 & 15 \\
\hline & 3,0 & 1,34 & 3 & 2,9 & 5,34 & 5 & 3.1 & 6.67 & 15 & 3.0 & 0.67 & 10 \\
\hline & 3,1 & 1,34 & 9 & 2.9 & 4,00 & 4 & 3.3 & 6.67 & 13 & 3.1 & 2.67 & 12 \\
\hline & 3,2 & 2,00 & 3 & 3.0 & 3.34 & 13 & 3,4 & 10,00 & 12 & 3,2 & 9,34 & 9 \\
\hline & 3,3 & 1.34 & 4 & 3.0 & 5.34 & 4 & 3,4 & 6.67 & 15 & 3,3 & 13,34 & 22 \\
\hline & 3.3 & 4,67 & 3 & 3.1 & 5.34 & 4 & 3,5 & 2.67 & 9 & 3.3 & 12.00 & 20 \\
\hline Mädia & 3,0 & 2.600 & 3 & 2.9 & 4.140 & 6 & 3.2 & 4,800 & 12 & 3.1 & 6.670 & 15 \\
\hline
\end{tabular}

A - NO número 4 ou 5, $\theta=$ NO número 8 ou 9, $O$ : 01âmetro do colmo, VF - Número de Vasos Funciona1s. Oentro de tratamentos,

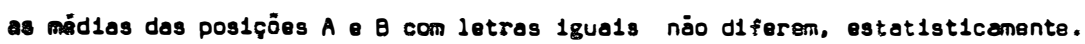

$$
\text { C.V.(z) } \text { trotamento }=82,10, \quad \text { C.V.(3) } 1 \text { posiçäo }=47.61
$$


.38 .

Nas Tabelas 6 e 7, a análise de variáncoa dos dados revelou que os tratamentos diferiram, significativamente, aos níveis $1 \%$ e $5 \%$, pelo Teste "F", respectivamente, para as cultivares 'CB45-3' e 'CP51-22', isto sem levar em consideração as posições dos nós no colmo. Por outro lado, as posições diferiram entre si ao nível de $1 \%$, dentro do tratamento térmico na determinação após colheita, para a cultivar 'C845-3'. Com relação a cultivar 'CP51-22', houve diferenças significativas entre as posições nos dois tratamentos para as determinações de vazão, efetuadas após colheita.

Observa-se também pelas Tabelas 6 e 7, que a vazão de água aumentou da posição A para B nas duas cultivares e diminuiu, quando os col mos foram armazenados. A análise de correlação entre o número de vasos fun cionais do xilema e a vazão revelou diferenças estatísticas, ao nível de $1 \%$, pelo Teste "F".

Com relação ao diâmetro do colmo, os dados apresentados nas Tabelas 6 e 7 mostram que a vazão independe do diâmetro considerado no colmo.

\subsubsection{Distribuição do RS dentro de touceira de cana-de-açücar}

A Tabela 8 , mostra as variações de vazão de ägua verificadas dentro da mesma touceira, em duas cultivares de cana, que foram tratadas ter micamente e inoculadas com RS. 
.39.

Tabela 8. Variação de vazão de água em colmos dentro de touceiras de cana-de-açúcar, tratadas termicamente e inoculadas com caldo bruto (RS).

\begin{tabular}{|c|c|c|c|c|c|}
\hline \multirow[t]{3}{*}{ Cultivares } & \multirow[t]{3}{*}{ colmos } & \multicolumn{4}{|c|}{$\begin{array}{l}\text { Vazão de contaminantes, por colmos, da mesma } \\
\text { touceira, à pressão de vácuo de } 30 \mathrm{~mm} \mathrm{Hg}\end{array}$} \\
\hline & & \multicolumn{2}{|c|}{ Caldo bruto (RS) } & \multicolumn{2}{|c|}{ Tratada } \\
\hline & & $\mathrm{ml} / 100^{\prime}$ & $\begin{array}{l}\text { Contami- } \\
\text { nantes }\end{array}$ & $\mathrm{ml} / 100^{\prime}$ & $\begin{array}{l}\text { Contami- } \\
\text { nantes }\end{array}$ \\
\hline \multirow{8}{*}{ 'IAC52/326' } & 1 & 13,34 & & 13,34 & $B, F$ \\
\hline & 2 & 2,00 & $\mathrm{~F}$ & 23,34 & \\
\hline & 3 & 5,34 & $B, F$ & 100,05 & $B, F$ \\
\hline & 4 & 5,34 & & 66,67 & $B, F$ \\
\hline & 5 & 20,01 & & 112,06 & \\
\hline & 6 & 3,34 & $\mathrm{~F}$ & 88,04 & \\
\hline & 7 & 5,34 & & 106,72 & $\mathrm{~F}$ \\
\hline & 8 & 6,67 & $\mathrm{~F}$ & 33,34 & $B, F$ \\
\hline \multirow[t]{3}{*}{. } & 1 & 53,34 & & 126,72 & $B, F$ \\
\hline & 2 & 40,03 & & 173,43 & \\
\hline & 3 & 33,35 & $B, F$ & 160,08 & $\mathrm{~B}$ \\
\hline \multirow[t]{5}{*}{$' C P 45-184 '$} & 4 & 3,34 & $B$ & 100,05 & \\
\hline & 5 & 53,34 & & 166,75 & \\
\hline & 6 & 73,37 & & 26,68 & $B, F$ \\
\hline & 7 & 60,03 & & 173,42 & \\
\hline & 8 & 33,35 & $\mathrm{~F}$ & 120,06 & $\mathrm{~F}$ \\
\hline
\end{tabular}

$B=$ Broca (Diatraea saccharalis), $F=$ Fusarium moniliforme 
.40.

Verificam-se que os resultados de determinação de vazão de água, dentro de toucelra, varlaram bruscamente em ambos os tratamentos das duas cultivares, devidoàs presenças de Broca e Fusarium, conforme observado na Tabela 8 .

\subsection{Isolamentos de contaminantes dos vasos do xilema}

A Tabela 9 refere-se aos resultados de 1solamento de Fusarium moniliforme, em tres cultivares de cana-de-açúcar, submetidas aos dife rentes tratamentos.

Tabela 9. Frequência de F. moniliforme em colmos de cana-de-açúcar, tratados termicamente e inoculados com caldo bruto (RS) e escaldadura das folhas.

\begin{tabular}{llcc}
\hline $\begin{array}{l}\text { Cultivares } \\
\text { Inoculadas }\end{array}$ & $\begin{array}{c}\text { Tratamento do } \\
\text { colmo de ca- } \\
\text { na-de-açúcar }\end{array}$ & $\begin{array}{c}\text { Número total de colmos/ } \\
\text { numero de colmos 1sola- } \\
\text { dos }\end{array}$ & $\begin{array}{c}\text { \% colmos } \\
\text { com Fusarium }\end{array}$ \\
\hline 'NA56-79' & Tratamento térm1co & $10 / 8$ & 80,00 \\
'IAC52/326' & Caldo bruto & $30 / 13$ & 43,34 \\
'IAC52/326' & Escaldadura & $30 / 17$ & 56,17 \\
'IAC52/326' & Tratamento térm1co & $30 / 16$ & 56,34 \\
'C0740' & Caldo bruto & $30 / 17$ & 56,67 \\
'C0740' & Escaldadura & $30 / 15$ & 50,00 \\
'C0740' & Tratamento térm1co & $30 / 18$ & 60,00 \\
\hline
\end{tabular}

- Média do 1solamento, efetuada em tres posiçōes do colmo de cana-de-açúcar. 
colmos de cana-de-açúcar ë bastante elevada, independente do tratamento con siderado.

Os resultados de determinação de vazão de água, em colmos de cana inoculados com cultura pura de $x$. albilineans, não diferiram do tratamento térmico, isto é, entre as repetições os resultados variaram muito:ora a vazão média era maior nos colmos inoculados, ora a vazão era maior nos colmos tratados termicamente. O isolamento e, consequente identificação da bactéria, através de serologia, utilizando o método do anel modifica do por MASUDA (dados não publicados), apresentaram indícios de precipitação em micropipetas sem, contudo, oferecer segurança na determinação da presença dessa bactéría.

5.3. Resultados de aplicação do método de vazão de āgua, em colmos, para avaliar a suscetibilidade das cultivares de cana-de-açūcar ao RS

5.3.1. Evolução da infestação de RS em cana-planta e la. soca

A Tabela 10 mostra os resultados de vazão média em cana-plan ta e cana soca das cultivares 'IAC52/326' e 'CO740', submetidas ao tratamen to térmico e inoculadas com RS.

Pela Tabela 10, verificam-se que as cultivares comportaram-se diferentemente, com relação à idade, pois enquanto que na cultivar 'IAC 52/326', a vazão média diminuiu no $2^{\circ}$ corte, na 'CO740', a vazão aumentou. A anälise de variância mostrou diferenças significativas, ao nível de 1\%,pelo Teste "F", entre os tratamentos no $2^{\circ}$ corte, apenas para a cultivar 'IAC $52 / 326^{\prime}$. 
Tabela 10. Avaliação da vazão média em dois cortes de canas, tratadas termi camente e inoculadas com caldo bruto (RS).

\begin{tabular}{|c|c|c|c|c|c|}
\hline \multirow{4}{*}{ Cortes } & \multirow{4}{*}{$\begin{array}{l}\text { Repeti } \\
\text { ções }\end{array}$} & \multicolumn{4}{|c|}{$\begin{array}{l}\text { Vazão média de } 12 \text { colmos/tratamento em } \mathrm{ml} / 100^{\prime} \text {, à } \\
\text { pressão média de vácuo de } 30 \mathrm{~mm} \mathrm{Hg}\end{array}$} \\
\hline & & \multicolumn{4}{|c|}{ Cultivares } \\
\hline & & \multicolumn{2}{|c|}{ 'IAC 52/326' } & \multicolumn{2}{|c|}{ 'CO740' } \\
\hline & & Caldo bruto & Tratado & Caldo bruto & Tratado \\
\hline \multirow{3}{*}{18} & 1 & 32,40 & 40,00 & 68,10 & 67,60 \\
\hline & 2 & 37,20 & 41,40 & 86,30 & 68,21 \\
\hline & 3 & 16,00 & 42,00 & 54,20 & 60,19 \\
\hline \multirow[t]{2}{*}{ Média } & & $28,54 a$ & $41,13 a$ & $69,54 a$ & $65,34 a$ \\
\hline & 1 & 8,04 & 38,84 & 62,68 & 113,36 \\
\hline \multirow[t]{2}{*}{28} & 2 & 7,00 & 40,34 & 85,70 & 55,68 \\
\hline & 3 & 6,13 & 16,77 & 108,71 & 79,36 \\
\hline Média & & $7,05 a$ & $31,98 b$ & $85,69 a$ & $82,80 a$ \\
\hline
\end{tabular}

$C \cdot V \cdot(\%)=34,88$

- Dentro de cultivar, as médias com letras iguais não diferem, estatisticamente.

5.3.2. Avaliação da vazão de ãgua, em colmos de cana-de-açúcar tratados termicamente e inoculados com RS

A Tabela 11 mostra a vazão média de água, em colmos tratados termicamente e inoculados com RS, correspondentes a tres cultivares de cana -de-açücar. 
Tabela 11. Avaliação da vazão média em colmos de cana-de-açúcar, tràtados termicamente e inoculados com caldo bruto (RS).

\begin{tabular}{|c|c|c|c|c|c|c|}
\hline \multirow{4}{*}{ Repetições } & \multicolumn{6}{|c|}{$\begin{array}{c}\text { Vazão média de } 16 \text { colmos/tratamento em ml/100', à } \\
\text { pressão de vácuo de } 30 \mathrm{~mm} \mathrm{Hg}\end{array}$} \\
\hline & \multicolumn{6}{|c|}{ Cultivares } \\
\hline & \multicolumn{2}{|c|}{ 'IAC52/326' } & \multicolumn{2}{|c|}{$\cdot C P 45-184^{\prime}$} & \multicolumn{2}{|c|}{${ }^{\prime} \cos 40^{\prime}$} \\
\hline & Caldo bruto & Tratado & Caldo bruto & Tratado & Caldo bruto & Tratado \\
\hline 1 & 15,87 & 54,54 & 28,62 & 110,34 & 69,53 & 68,66 \\
\hline 2 & 28,58 & 41,13 & 34,88 & 141,74 & 85,69 & 82,80 \\
\hline 3 & 7,05 & 31,98 & 51,97 & 133,39 & 88,71 & 93,36 \\
\hline 4 & 7,84 & 60,30 & 52,50 & 157,00 & 85,70 & 79,36 \\
\hline 5 & 23,90 & 47,95 & 42,52 & 112,27 & 55,68 & 62,68 \\
\hline Média & $16,65 a$ & $47,18 \mathrm{~b}$ & $42,09 a$ & $130,95 b$ & $77,06 a$ & $77,37 a$ \\
\hline
\end{tabular}

C.V. $(\%)=20,41$

- Dentro de cultivar, as médias com letras iguais não diferem, estatisticamente.

A análise de variância dos dados apresentados, na Tabela 11, acusou diferenças significativas, ao nível de $1 \%$, pelo Teste "F", entre os tratamentos para as cultivares 'IAC52/326' e 'CP45-184', enquanto o mesmo não ocorreur para a cultivar 'CO740'.

As Tabelas 12 e 13, mostram os dados referentes às determina ções de vazão média de água de cinço (5) cultivares de cana-de-açúcar, provenientes do experimento instalado a partir de mudas de viveiros secundários, com 20 meses de idade, que foram submetidas ao tratamento térmico e inoculadas com RS. 
Tabela 12. Avaliação da vazão média em colmos de cana-de-açücar, tratados termicamente e inoculados com caldo bruto (PS).

\begin{tabular}{|c|c|c|c|c|c|c|}
\hline \multirow[t]{3}{*}{ Cultivares } & \multirow[t]{3}{*}{ Tratamento } & \multicolumn{4}{|c|}{$\begin{array}{l}\text { Vazão média de } 16 \text { colmos/tratamento, } \\
24 \text { horas após a colheita, em ml/100' } \\
\text { a pressão de vácuo de } 30 \mathrm{~mm} \mathrm{Hg}\end{array}$} & \multirow[t]{3}{*}{ Média } \\
\hline & & \multicolumn{4}{|c|}{ Repetições } & \\
\hline & & 1 & 2 & 3 & 4 & \\
\hline \multirow[t]{2}{*}{ 'NA56-79' } & Caldo bruto & 3,29 & 4,00 & 3,17 & 6,64 & $4,27 a$ \\
\hline & T. térmico & 7,25 & 7,54 & 5,75 & 11,50 & $8,01 b$ \\
\hline \multirow[t]{2}{*}{ 'IAC52/326' } & Caldo bruto & 12,29 & 3,58 & 3,50 & 5,75 & $6,28 a$ \\
\hline & T. térmico & 16,45 & 6,21 & 9,33 & 15,15 & $11,78 b$ \\
\hline \multirow[t]{2}{*}{$' C B 47-355^{\prime}$} & Caldo bruto & 18,17 & 4,58 & 4,46 & 4,46 & $7,91 a$ \\
\hline & T. térmico & 22,21 & 3,62 & 5,25 & 3,63 & $8,58 a$ \\
\hline \multirow[t]{2}{*}{ 'CE41-14' } & Caldo bruto & 18,54 & 5,10 & 4,50 & 2,91 & $7,76 a$ \\
\hline & T. térmico & 13,88 & 12,87 & 13,17 & 4,33 & $11,06 a$ \\
\hline \multirow[t]{2}{*}{ 'CB41-76' } & Caldo bruto & 12,15 & 3,79 & 3,37 & 2,92 & $5,56 a$ \\
\hline & T. térmico & 12,15 & 4,24 & 8,17 & 6,67 & $7,80 a$ \\
\hline
\end{tabular}

- Dentro de cultivar, as médias com letras iguais não diferem, estatisticamente.

$C \cdot V \cdot(\%)=30,68$ 
Tabela 13. Avallação da vazão médla em colmos de cana-de-açúcar, tratados termicamente e inoculados com calde bruto (PS).

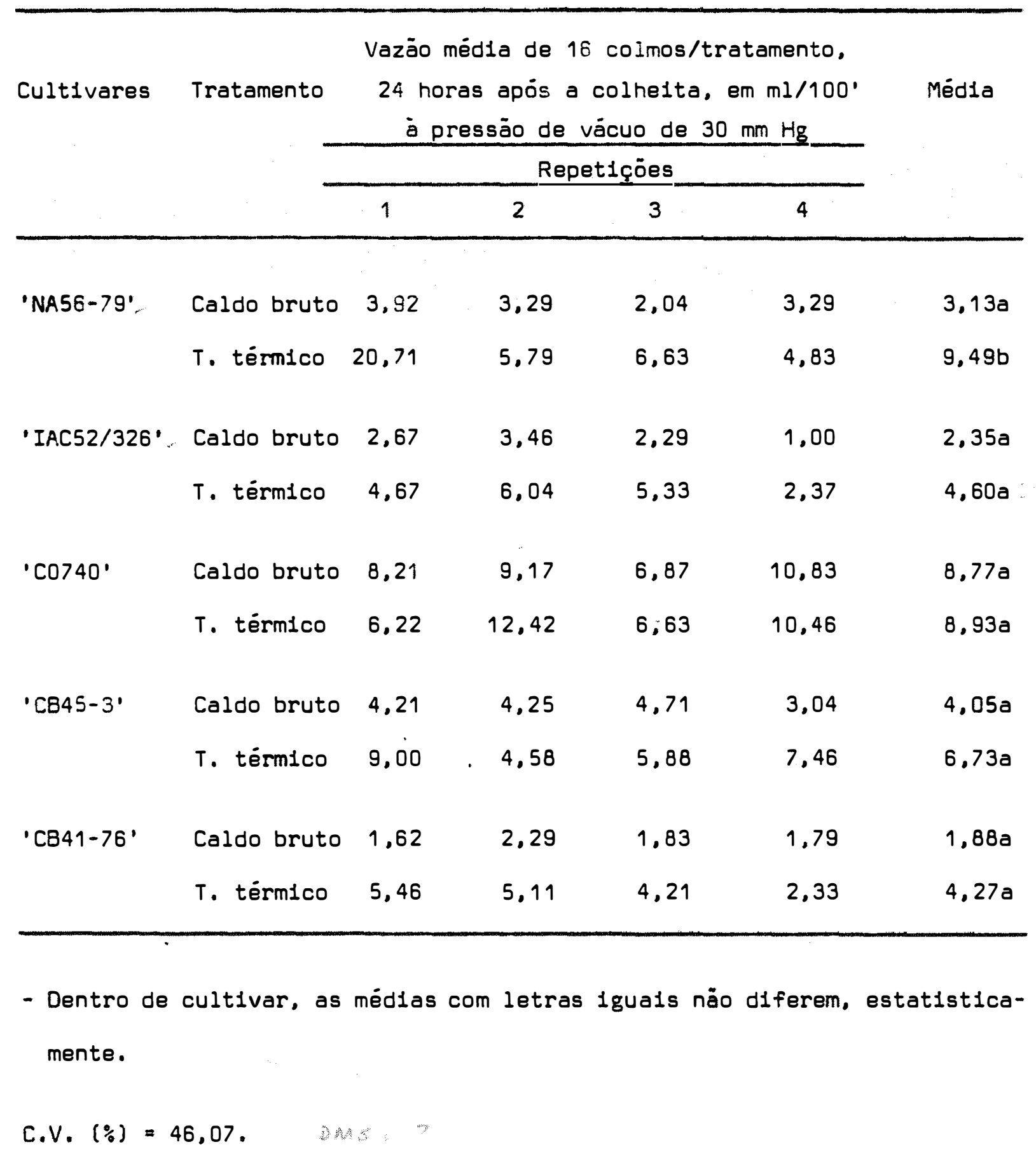


Pelas Tabelas 12 e 13 , verificam-se que as cultivarès tive ram comportamentos semelhantes com relação aos tratamentos à que foram submeticas, isto é, a vazão de água fol sempre maior no tratamento térmico. A análise de variància da Tabela 12 acusou, pelo Teste "F", diferenças significativas, aos níveis de $5 \%$ e $1 \%$, entre os tratamentos, somente para as cul tivares 'NA56-79' e 'IAC52/326', respectivamente. Por outro lado, pela Tabela 13, as diferenças foram significativas, ao nível de $1 \%$ entre os tratamentos, somente para a cultivar 'NA56-79'.

5.4. Medidas dos diâmetros do lume dos vasos do xilema de colmos de cana -de-açūcar

A Tabela 14, mostra as médias estimadas da medida dos diāmetros do lume de 600 vasos do xilema por cultivar, através do Intérvalo de Confiança apresentado para duas cultivares de cana-de-açücar.

Tabela 14. Médias estimadas e Amplitude do Intervalo de Confiança de duas cultivares de cana-de-açücar.

Cultivares

Média do diàmetro da luz dos vasos e Intervalo de Confiança das médias

' IAC52/326'

$96,55 \mu \pm 0,77$

'NA56-79'

$96,89 \mu \pm 0,72$ 
Pela Tabela 14, observam-se que as médias dos diàmetros da luz dos vasos do xilema foram muito próximas entre si. Por outro lado, verifica-se também que a Amplitude do Intervalo de Confiança da cultivar 'IAC 52/326' foi, praticamente, a mesma da cultivar 'NA56-79'. 
.48 .

6. DISCUSSÃO

Inicialmente, serão discutidos os resultados referentes às determinações de vazão de água, considerando a influência de cada fator, isoladamente, ou em conjunto em seguida, os resultados alcançados com a aplicação do método de vazão para avaliar o RS em cultivares de cana-de-açú car.

Em todos os fatores testados, tais como: pressão de vácuo, sentido do colmo, localização dos nós no colmo, diāmetro do colmo, armazena mento do colmo, outras doenças vasculares, colmos brocados, idade do colmo e distribuição da doença dentro de touceira, a vazão de água foi sempre determinada e comparada entre colmos de cana-de-açúcar, tratados termicamente (sadios) e inoculados com caldo bruto (doentes).

6.1. Fatores que interferem no método de avaliação do RS

Para estudar o efeito da pressão de vácuo, no método de vazão de ägua, tomamos como referência a pressão inicial de văcuo de $30 \mathrm{~mm}$ 
$\mathrm{Hg}$, pois menores pressões não deram vazão para algumas cultivares testadas.

Verificam-se através da Tabela 1, que houveram notórias di ferenças de vazão entre o caldo bruto e o tratamento térmico, quando se apli cou uma pressão de vácuo de $30 \mathrm{~mm} \mathrm{Hg}$ para as duas cultivares, que são consi diredas altamente suscetiveis ao RS. As alterações nos feixes vasculares da região nodal do colmo de cana-de-açúcar ou devido à presença física do agente causal ou à reação da planta, através da emissão de tiloses ou liberação de substâncias gomosas, obstruindo a passagem de água nos vasos condu tores, foi confirmada pela sintomologia bem evidente na região nodal dos colmos inoculados com RS. Com a aplicação de uma pressão de vácuo igual ou maior do que $70 \mathrm{~mm} \mathrm{Hg}$, a vazão aumentou, mas a diferença entre os tratamen tos diminuiu, indicando, provavelmente, que a pressão interferiu, no funcionamento dos vasos condutores. Por outro lado, esses resultados indicamque, se determinássemos a vazão em cultivares menos suscetíveis ao RS, a aplicação dessa alta pressão não acusaria diferença entre os tratamentos, devido à queda de precisão no método.

Portanto, a partir dos resultados da Tabela 1, a melhor dife rença de vazão se verificou com a aplicação da pressão de vácuo de $30 \mathrm{~mm}$ $\mathrm{Hg}$, coincidindo com aquela utilizada por TEAKLE et alii, 1975, no estudo da possível correlação de resistência de cana-de-açūcar ao RS com anatomia vas cular.

Pela análise dos dados apresentados na Tabela 2 , verifica-se que, dentro do mesmo colmo, o sentido considerado não interfere nas determi nações de vazão, ao passo que, em colmos diferentes, a vazão foi menor no sentido inverso ao da subida da seiva inorgànica no colmo. Essa indicação 
nos mostra que a vazão é sempre maior no sentido normal do colmo e que ela decresce com o tempo de determinação. Portanto, diminuindo o tempo gasto para as análises individuais, podemos analisar maior número de amostras, no mesmo período de tempo, e aumentarmos a precisão do método, diminuindo o pe ríodo de armazenamento que interfere nas determinaçōes, como veremos mais adiante. Esse decréscimo de vazão, com o tempo, está de acordo com as observaçōes verificadas por TEAKLE et alii (1975).

Com relação à vazão dentro do mesmo colmo, os resultados apresentados nas Tabelas 3 e 4 indicam que existe uma forte tendência em au mentar a vazão de água, partindo-se da base para o ápice do colmo. Essa maior ou menor diferença de vazão, entre as diferentes posiçōes tomadas no colmo, deve, provavelmente, estar na dependência da cultivar, da idade e ma turação do colmo e da distribuição da doença RS, no colmo. TANIMOTO (1964) verificou através do exame histológico de cortes, com micrótomo da secção nodal de colmos de cana-de-açücar, que o número de feixes fibro-vasculares é o mesmo dentro do colmo, independentemente, do nó considerado. Por outro lado, ARTSCHWAGER (1925), CORNELISON e COOPER (1941) In DILLEWIJN (1952) citaram que a deposição de compostos semelhantes à lignina, nas paredes interna e externa dos feixes fibro-vasculares, está em proporção direta com a idade e tamanho dos feixes. Isto explica porque a vazão é menor na base do colmo, onde ocorre maior deposição dos compostos, diminuindo o diāmetro do lume dos vasos do xilema.

Portanto, como a vazão é variável dentro do colmo e, baseado em observações de diversos autores, tais como HUGHES e STEINDL (1955), de que a doença, normalmente, é encontrada nos nós mais maduros do colmo, fixa 
nos, para as determinações de vazãc, o nó número 4 ou 5 da base do colmo, estando essa flexibilidade na dependência da presença ou não da broca da ca na-de-açücar.

Pelos resultados zitados na Tabela 5 e, de acordo com a análise de variáncia, verifica-se que o armazenamento de colmos de cana-de-açú car pode constituir-se num importante fator de interferência no método de vazão, uma vez que ele conduz à uma queda brusca na vazão de água, dificultando a avaliação das cultivares ao RS. Essa queda de vazão deve ser devido à interferência que ocorre no equilíbrio hídrico das células vegetais . No entanto, essa interferência está ainda, na dependência do período e das condições de armazenamento e da cultivar testada, uma vez que o armazenamen to por 24 horas, diminuiu a diferença entre os tratamentos, embora continuasse a ser significativa nas duas cultivares testadas, que são considera das altamente suscetíveis ao RS. Segundo EGAN et alii (1977), a deterioração das cultivares, logo após a colheita, é função de diversos fatores, entre os quais destacam-se: tipo de infecção microbiana, tempo de armazena mento, condições climáticas e cultivar utilizada. Portanto, torna-se neces sário fazer as determinações de vazão das amostras, logo após a colheita. para evitar o efeito do armazenamento, nos resultados de avaliação das cultivares ao RS.

De acordo com os dados apresentados nas Tabelas 6 e 7 , obser va-se que a vazão independe do diâmetro do colmo. Segundo TANIMOTO (1964), - diámetro do colmo de cana-de-açúcar é uma característica varietal, que de pende de inúmeros fatores culturais e ambientais. Esse autor concluiu que, em dez clones investigados, o número de feixes foi, essencialmente, o mesmo 
em cada clone. Por outro lado, observa-se que a variação no diāmetro e o número de colmos por touceira, fol o mesmo em ambos os tratamentos, para as duas cultivares testadas, indicando que a presença de RS nem sempre provoca a queda de perfilhamento e diminuição no diàmetro dos colmos. Portanto, a sintomatologia externa, como meio de diagnose, como foi enfatizada, nem sem pre é vālida.

A utilização do método da tinta nanquim para colorir os vasos do xilema, responsáveis pela condução de água, trouxeram excelentes informações. Primeiramente, mostrou que existe uma correlação positiva entre a vazão e o número de vasos funcionais, mesmo em determinações de 120 horas após colheita. Por outro lado, pode constituir-se numa prova a mais, de que o RS obstruiu os vasos funcionais, diminuindo a vazão dentro do colmo. Além disso, verifica-se, através desse método auxiliar, que o número de vasos funcionais variou dentro do colmo, confirmando a teoría da deposição de compostos nas paredes dos vasos, diminuindo o diàmetro do lume, de modo a dificultar a passagem de água, através dos colmos, conforme mostram as Tabe las 6 e 7. Essa correlação positiva concordou com os resultados obtidos no estudo sobre a natureza da resistência da cana-de-açūcar à Podridão VermeIha por ATKINSON (1938), ao RS por TEAKLE et alii (1975) e em tomate à Mur cha de Fusarium, por SAALTINK e DIMOND (1964).

Apesar dos dados apresentados nas Tabelas 6 e 7 mostrarem a correlação positiva entre a vazão e o número de vasos funcionais, sigeriu-se que o método auxiliar da tinta nanquim devesse ser repetido com outras cultivares, devido à análise de variància mostrar um coeficiente de variação muito alto, em decorrência talvez da imprecisão nos resultados. 
Além da presença de contaminantes como a broca e, principalmente, o Fusarium, citados na Tabela 8 , outros fatores podem ser mencionados como responsáveis pela varịação brusca de vazão de água dentro de touceiras, tais como: idade e maturação do colmo; distribuição irregular de microorganismos, no colmo; outras doenças vasculares; fatores intrínsecos da planta; tipos de solo; fatores culturais e ambientais e cultivares de ca na-de-açúcar. Porém, entre todos esses fatores mencionados, a presença de Fusarium, idade e maturação do colmo, e distribuição irregular de microorga nismos, são, provavelmente, os mais importantes e responsáveis pela variação, desde que a determinação seja conduzida logo após a colheita.

Os resultados observados nas Tabelas 8 e 9 , indicam que a presença de Fusarium nos colmos é constante, independente da cultivar e do tratamento considerado.

Com relação à Escaldadura das Folhas, os resultados obtidos, mas não publicados, de determinação da vazão e isolamento, indicam que, devido ao tratamento térmico nạo controlar totalmente a Escaldadura das Fôlhas, provavelmente, este não tenha servido como testemunha, sugerindo, a necessidade de um estudo mais apurado quanto à eficiència do método de vazão, para avaliar a resistência das cultivares de cana-de-açücar à essa doença. -

\subsection{Aplicação do mētodo de vazão de ãgua para avaliação do RS}

Conforme observam-se pelos resultados, as comparaçōes de vazão são sempre efetuadas entre os tratamentos: colmos tratados termicamente 
contra o RS (sadios) e inoculados com RS através do caldo bruto (dcentes?, sempre dentro da mesma cultivar de cana-de-açúcar.

As Tabelas 10, 11, 12 e 13 referem-se à aplicação do método de vazão de água, para avaliar as cultivares, com relação ao RS.

A Tabela 10 mostra que o comportamento diferencial, verificado para as cultivares 'IAC52/326' e 'C0740; através da vazão de água, deve-se ao grau de suscetibilidade ao RS. Verificou-se a evolução da doença do $1^{\circ}$ corte para o $2^{\circ}$ corte, somente para a cultivar 'IAC52/326', que foi confirmada pelo exame de sintomas internos no tratamento caldo bruto. 0 tra tamento térmico dessa cultivar mostrou algum indicio de sintoma interno, ex plicando a ocorrência de reinfestaçōes do RS, principalmente, nas cultivares mais suscetíveis, como é esse caso. Apesar do coeficiente dé variação ser alto, os resultados obtidos confirmaram o comportamento dessas cultivares verificado na prática.

Os resultados obtidos na Tabela 11 indicam que as cultivares 'IAC52/326' e 'CP45-184' 'podem ser consideradas altamente suscetiveis e a cultivar 'CO740', como intermediária ao RS, na escala de notas. A sintomatologia interna confirmou os resultados alcançados na vazão e, também, o comportamento observado na prática.

Pelas Tabelas 12 e 13, observa-se que sempre a vazão média do tratamento térmico foi maior do que a do caldo bruto para cada cultivar. Al gumas cultivares mostraram diferenças marcantes de vazão entre os tratamentos, enquanto que em outras, a diferença foi pequena ou, práticamente, não houve diferença entre os tratamentos, indicando menor grau de suscetibilida 
.55 .

de ao RS. Contudo, a determinação da vazão 24 horas após colheita, interferiu nos resultados, pois a análise de variāncia acusou diferenças signifi cativas, apenas para as cultivares 'IAC52/326' e 'NA56-79'. Conforme era esperado, a cultivar 'IAC52/326' mostrou ser suscetivel ao RS mais uma vez, confirmado pela sintomatologia interna bem visível. Por outro lado, a cultivar 'NA56-79', que vem se expandindo, rapidamente, no Estado de São Pau10, ocupando,atualmente, de 17 a $20 \%$ da área de plantio da cana-de-açúcar. em nenhum levantamento tem sido considerada suscetível ao RS. Apesar de não apresentar sintomatologia interna apreciável e ser responsável por uma elevada produtividade, acredita ser a cultivar 'NA56-79' suscetivel ao RS. Isto significa que essa cultivar poderia alcançar uma maior produção por unidade de área, caso fosse evitada a presença evolutiva de infestação do RS.

Ainda com relação às Tabelas 12 e 13, outro fator responsável pela ausência de diferenças significativas entre os tratamentos para al gumas cultivares, que são consideradas suscetiveis ao RS, seja talvez o coe ficiente de variação alto, obitido na análise de variāncia. Um maior número de repetiçōes nos experimentos, poderia ser uma maneira de aumentar a preci são do método.

Os resultados de determinação de vazäo indicam que um ou mais mecanismos podem ser responsáveis pelo comportamento diferente das cul tivares, com relação à presença do RS. Baseado na observação de que a passagem de água, através dos colmos, dá-se pelos vasos do xilema e que a doen ça è de natureza vascular, mediram-se os diâmetros do lume dos vasos dos cul tivares 'IAC52/326' e. 'NA56-79'. Os resultados da Tabela 14, mostram não 
.56 .

haver diferenças entre os diâmetros do lume dos vasos das duas cultivares. Como os resultados de vazão para essas duas cultivares foram muito semelhan tes, consideram-se que, tiveram o mesmo comportamento diante do RS. A escolha, provavelmente, não fol adequada para efetuar esse tipo de análise. Portanto, sugerem-se novos testes de vazão, com outras cultivares de compor tamentos extremos aos resultados obtidos com às determinaçōes de vazão, a fim de verificar se a anatomia vascular está ou não envolvida na resistēn cia ao RS. 


\section{CONCLUSÖES}

Dos resultados obtidos, as segulntes conclusões foram Infer 1 das:

1. Há correlação entre a diferença de vazão de água em colmos sadios e doentes de cana-de-açücar e o grau de suscetibilidade ao Raqu1 tIsmo da Soquelra,

2. Excetuando-se o diâmetro do colmo, os fatores: armazena mento, pressâo de vảcuo, sentido do colmo, localização dos nós no colmo, tempo de determinação, outras doenças vasculares, colmos brocados, 1dade dos colmos e a distribulçāo do RS dentro de toucelra, Interferem na determ1 nação da vazão de águas

3. Acreditam-se que os fatores: tipos de solo, regime pluviométrico, tratos culturals e podridóes de raízes, devem Interferir no método de vazão de águas

4. A vazão de ägua em colmos de cana-de-açūcar é diretamente 
.58 .

proporcional ao número de vasos funcionais do xilema;

5. O RS tem uma distribuição desuniforme dentro da touceira de cana-de-açúcar e a intensidade de ataque aumenta com a idade da culturas 6. A cultivar 'NA56-79' não apresentou sintomas internos apreciáveis, porém mostrou ser bastante suscetível ao RS, pelo método de vazão de água;

7. Os resultados indicam ser possível avaliar a suscetibilidade das cultivares ao RS, pela determinação de vazão de água e, esta pode constituir-se num método rápido, econômico e eficiente de seleção de plantas resistentes ao RS e de outras doenças vasculares da cana-de-açücar. 


\section{SUMMARY}

The control of ratoon stunting disease (RSD) has been unsatisfactory, mainly to the fact that the identification of RSD through unspecific symptom is questionable. The roguing used with success to control other sugarcane diseases is imposible to apply without a specific external symptom. The development of resistant varieties is difficult since an efficient and quick method of screening is not avallable.

As an attempt to solve the problem the method of measuring the water flux on sugarcane stalks was developed. Water was passed through healthy and diseased sugarcane cuttings. The RSD effect on water flux was measured in commercial and differential varieties for RSD. The effect of several factors on water flux was measured on healthy and diseased cuttings under constant vacuum.

The results indicate, that excepting the stalk diameter, the factors as storage, vacuum pressure, node direction, position of node in stalks, stalks injured by Diatraea saccharalis and other vascular diseases 
.60.

interfered on water flux evaluation.

The statistical analyses of water flux data indicated that in varieties tolerant to RSD, the drop of water flux between healthy and diseased cuttings is small, while on susceptible varieties the opposite was observed.

The ocurrence of correlation between drop of water flux, RSD symptons in nodes and smaller number of functional vascular bundles was observed.

From results and discussion, the conclusion that the determination of water flux in healthy and diseased stalks can become an efficient, safe, fast and cheap method of screening plants resistant to RSD and to the other vascular diseases of sugarcane was inferred. 


\section{LITERATURA CITADA}

ABBOTT, E.V. e C.G. HUGHES, 1961. Red rot. In: MARTIN, J.P., E.V. ABBOTT e C.G. HUGHES, eds. Sugarcane Diseases of World. Amsterdam, Elsevier, v. 1. p. 263-282.

ABBOTT, E.V., N. ZUMMO e R.L. TIPPETT, 1967. Methods of testing sugarcane varieties for disease resistance at the varieties susceptible. Proceedings of the 12th Congress. International Society of Sugar Cane Technologists, Puerto Rico, 1965, p. 1138-1142.

ARTSCHWAGER, E., 1925. Anatomy of the vegetative organs of sugarcane. Journal of Agricultural Research, 30(3): 197-221.

ARTSCHWAGER, E., 1960. Sieve tube lignification in sugarcane and its relation to the ratoon stunting disease. Proceedings of the 10th Congress. International Society of Sugar Cane Technologists, Honolulu, 1959, p. $1077-1083$ 
.62.

ATKINSON, R.E., 1938. On nature of resistance of sugarcane to red rot. Proceedings of the 6 th Congress. International Society of Sugar Cane Technologists, Baton Rouge, p. 684-692.

BAILEY, R.A., 1976. Some observations on the bacterium associated with ratoon stunting disease of sugarcane. Proceedings of the South African Sugar Technologists' Association, Durban, p. 60-64.

BAILEY, R.A., 1977. The systemic distribution and relative occurence of bacteria in sugarcane varieties affected by ratoon Stuting disease. Proceedings of the South African Sugar Technologists' Association, Durban, p. 55-56.

BARNETT, H.L. e B.B. HUNTER, 1972. IIZustrated Genera of Imperfect Fungi. 3a. ed. Minneapolis, Burgess; $241 \mathrm{p}$.

BOZICEVICH, J.H., H.A. SCOTT e M.M. VICENT, 1963. The bentonite flocculation teste for detection of plant viruses and tetration of antibody. Proceedings of the Society for Experimental Biology and Medicine; New York, $114: 750-754$.

CAMPBELL, D.H., J.S. GARVEY, N.E. CREMER e D.H. SUSSDORF, 1970. Methods in Immosology. 2 ed. New York, Benjamin, 454 p.

CARVALHO, P.C.T., 1963. As viroses da cana-de-açücar. In: Pragas e Doenças da Cana-de-açücar. Piracicaba, ESALQ/Dep. de Fitopatologia e Entomo logia, p. 75-90. 
CHEN, C.T., S.M. LEE e M.J. CHEN, 1975. Small coryneform bacteria in ratoon stunted sugarcane. Sugarcane Pathologists Newsletter, Sydney $(13 / 14): 6-8$

CHO, Y.S., R.D. WILCOXSON e F.I. FROSHEISER, 1973. Differences in anatomy, plant extrats, and movement of bacteria in plants of bacterial wilt resistant and susceptible varieties of Alfalfa. Phytopathology, Lancaster, $63: 760-765$.

CORNELISON, A.H. e H.F. COOPER, 1941. Further studies in nitrogen nutrition. The application of nitrogen test. Hawaiian Planters' Records, Honolulu, 45: 155-178.

DAMANN, K.E. Jr. e K.S. DERRICK, 1976. Bacterium associated with ratoon stunting disease in Louisiana. Sugarcane Pathologists Newsletter Sidney $(15 / 16)-20: 22$.

DAMANN, K.E. Jr., K.S. DERRICK, A.G. GILLASPIE Jr., B.F. FONTENOT e J. KAO, 1977. Detection of the RSD-associated bacterium by serologically specific electron microscopy. Proceedings of the 16th Congress. International Society of Sugar Cane Technologists, São Paulo. (no prelo).

DANTAS, B., 1956. Plano quadrienal para o estudo das principais doenças e pragas da cana-de-açúcar em Pernambuco. Recife, 58p. (Publicação 2, Co missão de Combate às Pragas da Cana-de-Açúcar no Estado de Pernambuco).

DILLEWIJN, C.V., 1952. Botany of Sugarcane. Waltham, Mass., Chronica Bota nica, $v, 1, p, 1-23$. 
DIMOND, A.E., 1955. Pathogenesis in the wilt diseases. Annual Review of Plant Physiology, Palo Alto, 6:329-350.

EGAN, B.T., L.K. KIRBY e A.G. NOBLE, 1977. A review of recent developments concerning the biodeterioration of sugarcane. Proceedings of the 16th Congress. International Society of Sugar Cane Technologists, São Paulo, v.1, p. $321-326$.

ELGERSMA, D.M., 1970. Lenght and diameter of xylem vessels as factors in resistance of elms to C. ulmi. Netherlands Journal of Plant Pathology, Wageningen, $76: 179-182$.

FORBES, I.L. e K.C. LING, 1960. Particles associated with the ratoon stunting disease of sugarcane. Sugar Journal, New Orleans, $23(2): 15$.

GALLI, F., H. TOKESHI, P.C.T. CARVALHO, E. BALMER, H. KIMATI, C.O.N. CARDOSO e C.L. SALGADO, 1968. Manual de Fitopatologia; Doenças das plantas e seu controle. São Paulo, Ed. Agronômica Ceres, 640 p.

GILLASPIE Jr., A.G., J.E. IRVIINE e R.L. STEERE, 1966. Ratoon stunting disease virus assay technique and partial purification. Phytopathology, Lancaster, $56: 1426-1427$.

GILLASPIE Ir., A.G., 1970. Evidence that ratoon stunting disease of sugar-cane is caused by virus and not mycoplasma. Phytopathology, Lancaster, $60: 1448-1450$.

GILLASPIE Jr., A.G., 1971. Ratoon stunting disease virus: problems in purification. American Society of Sugar Cane Technologists, Baton Rouge, $1: 52-56$ 
GILLASPIE Jr., A.G., R.E. DAVIS e J.F. WORLEY, 1973. Diagnosis of ratoon stunting disease based on the presence of a specific microorganism. Plant Disease Reporter, Washington, 57(12):987-990.

GILLASPIE Jr., A.G., R.E. DAVIS e J.F. WORLEY, 1976a. Nature of the bacterium associated with ratoon stunting disease of sugarcane. Sugar cane Pathologists Newsletter, Sydney (15/16):11-15.

GILLASPIE Jr., A.G., G. FLAX e H. KOIKE, 1976b. Relationship between nembers of diagnostic bacteria and injury by ratoon stunting disease in sugarcane. Plant Disease Reporter, Washington, 60(7):573-575.

GILLASPIE Jr., A.G., 1977. Ratoon stunting disease of sugarcane: serology. Phytopathology, Lancaster, 68:529-532.

HUGHES, C.G. e D.R.L. STEINDL, 1955. Ratoon stunting disease of sugarcane. Technical Commonication. Queensland Bureau of Sugar Experiment Stations, Brisbane, n. 2, $54 \mathrm{p}$.

HUGHES, C.G., 1956. Disease investigations: Ratoon stunting disease. Annual Report. Queensland Bureau of Sugar Experiment Stations, Brisbane, ก. 56, p. $81-84$.

HUGHES, C.G. e D.R.L. STEINDL, 1956. Some further developments in the study of ratoon stunting disease in Queensland. Proceedings of the 9th Congress. International Society of Sugar Cane Technologists, New Delhi, p. 1012-1022. 
HUGHES, C.G., 1960. Disease investigations: Ratoon stunting disease.

Annual Report. Queensland Bureau of Sugar Experiment Stations, Brisbane, ก. $60,0.82-83$.

IRVINE, J.E., 1975. Factors affecting the expression of juvenile symptoms of the ratoon stunting disease. Proceedings of the American Society of Sugarcane Technologists, Baton Rouge, p. 108-113.

JONES, F.R., 1934. Testing alfalfa for resistance to bacterial wilt. Journal of Agricultural Research, Washington, 48:1085-1098.

KAMIUNTEN, H. e S. WAKIMOTO, 1976. Coryneform bacteria found in xylem of the ratoon stunting diseased sugarcane. Annals of the Phytopathological Society of Japan, Tokyo, $42(4): 500-503$.

KHURANA, S.M.P., 1972. Causal organisms of RSD. Sugarcane Pathologists Newsletter, Sydney $(8): 15$.

LUDWING, R.A., 1952. Studies on the physiology of hadromy cotiledony wilting in the tomato plant. Technical Bulletin. Mac-Donald College. McGill University, Montreal, n. 20, 38p.

MARAMOROSCH, K., B. PLAVSIC-BANJAC, J. BIRD e L.J. LIU, 1973. Electron microscopy of ratoon stunted sugarcane: Microorganisms in xylem. Phytopathologische Zeitschrift, Berlin, 77:270-273.

MATSUOKA, S., 1971a. Virus do raquitismo da soqueira. In: COSTA, A.S., coord., Virologia. Piracicaba, Dep. Fitopatologia-ESALQ, v. 1, p.130135. 
MATSUOKA, S., 1971b. Elephant-grass, an indicator plant for ratoon stunting virus of sugarcane. Plant Protection Bulletin FAO, Rome, $9(5)$ : 110-115.

MATSUOKA, S., 1971c. Incidência do vírus do raquitismo da soqueira em canas provenientes de material propagativo tratado termicamente. Revista da Sociedade Brasileira de Fitopatologia, Mossoró, 4:63-64.

MATSUOKA, S., 1972a. Ratoon stunting disease diagnosis with elephant-grass as an indicator plant. Sugarcane Pathologists Newsletter, Sydney(8):1011.

MATSUOKA, S., 1972b. Raquitismo da soqueira da cana-de-açúcar: diagnose da moléstia e estudos sobre o seu agente causal. Piracicaba, ESALQ/USP, 77p. (Tese de Doutoramento).

MATSUOKA, S., 1975. Disseminação e controle do raquitismo da soqueira da cana-de-açūcar. Summa Phytopathologica, Piracicaba, 1(4):245-257.

PELTIER, G.L. e F.R. SCHROEDER, 1932. The nature of resistance in alfalfa to wilt (Aplanobacter insidiosum L. Mc.). Research Bulletin Nebraska Agricultural Experimental Station, Lincoln, $n^{8} 63,28 \mathrm{p}$.

PLAVSIC-BANJAC, B. e K. MARAMOROSCH, 1972. Electron microscopy of the xylem of ratoon stunted sugarcane. Phytopathology, Lancaster, 62:498-499.

RICAUD, C., 1974. Problems in the diagnosis of ratoon stunting disease. Proceedings of the 15th Congress. International Society of Sugar Cane Technologists, Durban, p.241-248. 
RICAUD, C., S. SULLIVAN e J.C. AUTREY, 1976. Presence of the RSDassociated bacterium in Mauritius. Sugarcane Pathologists Newsletter, Sydney, (17):37-39.

ROSSLER, L.A., 1974. The effects of ratoon stunting disease on three sugarcane varieties under different irrigation regimes. Proceedings of the 15th Congress. International Society of Sugar Cane Technologists, Durban, p.250-257.

SAALTING, G.J. e A.E. DIMOND, 1964. Nature of plugging material in xylem and its relation to rate of water flow in Fusarium-infected tomato stems. Phytopatology, Lancaster, 54: 1137-1140.

SCHEXNAYDER, C.A., 1956. The effect of stunting disease of sugarcane on yields of cane and sugar in Louisiana, and the use of heat treatment for control. Sugar Bulletin, New Orleans, 34(22):349-355.

SCHEXNAYDER, C.A., 1960. The use of a sugarcane "test plant" as a means of detecting the presence of ratoon stunting disease in sugarcane. Proceedings of the 10th Congress. International Society of Sugar Cane Technologists, Honolulu, 1959, p.1068-1072.

SILVA, W.M., 1976. Termoterapia em gemas isoladas assegura o controle do raquitismo. Boletim Técnico da Copersucar, Piracicaba, $76 \mathrm{p}$.

SINGH, G.R., 1969. An indicator sugarcane variety for ratoon stunting disease. Current Science, Bangalore, 38(9):221-222. 
STEIB, R.J. e D.M. TANTERA, 1970. Studies to determine the effect of tetracycline antibiotic on the ratoon stunting disease (RSD) of sugarcane. Sugar Bulletin, New Orleans, 48(17):217-219.

STEIB, R.J. e S.J.P. CHILTON, 1972. Losses causes by ratoon stunting disease and need for hot air treatment. Sugar Buzletin, New Orleans, 50 $(19): 8-11$

STEIB, R.J. e O.M. CIFUENTES, 1976. Control of RSD of sugarcane by use of aerated steam. Sugar Journal, New Orleans, 39(2):20-23.

STEINDL, D.R.L., 1957. Host range of the sugarcane ratoon stunting virus. Journal of the Australian Institute of Agricultural Science, Sydney, 23: 238.

STEINDL, D.R.L., 1961. Ratoon stunting disease. In: MARTIN, J.P., E.V. ABBOTT e C.G. HUGHES, eds. Sugarcane Diseases of the World. Amsterdam, Elsevier, v.1, P. 433-459.

STEINDL, D.R.L. e D.S. TEAKLE, 1975. Recent developments in the identification of ratoon stunting disease. Brisbane Bureau of Sugar Experimental Stations, P.101-104.

STEINDL, D.R.L., 1976a. The use of phase contrast microscopy in the identification of ratoon stunting disease. Brisbane, Bureau of Sugar Experimental Stations, p.71-72.

STEINDL, D.R.L., 1976b. Pathology research developments: New method of identifying ratoon stunting disease. Cane Growers' Quarterly Bulletin, Brisbane, $44: 130-131$. 
TANIMOTO, T., 1964. Microtome-slice projections for histological examination of sugarcane. Hcwaiian Planters' Records, Honolulu, $57(2)$ : $119-132$.

TEAKLE, D.S., P.M. SMITH e D.R.L. STEINDL, 1973. Association of a small coryneform bacterium with the ratoon stunting disease of sugarcane. Australion Journal of Agricultural Research, Melbourne, 24:869-874.

TEAKLE, D.S., 1974. The causal agent of sugarcane ratoon stunting disease (RSD). Proceedings of the 15th Congress. International Society of Sugar Cane Technologists, Durban, p.225-233.

TEAKLE, D.S., P.M. SMITH e D.R.L. STEINDL, 1975. Ratoon stunting disease of sugarcane: Possible correlation of resistance with vascular anatomy. Phytopathology, Lancaster, 65(2):138-141.

THOMPSON, G.M., 1960. Cane diseases: Ratoon stunting disease. Cane Growers' Quarterly Bulletin, Brisbane, 16:79-95.

TOKESHI, H., A. SANGUINO e F. AKIḄA, 1974. X. albilineans, provāvel agente causal de raquitismo da soqueira e escaldadura de cana-de-açúcar. Brasil Acucareiro, Rio de Janeiro, 84(6):28-40.

TUITE, J.,.1969. Plant Pathological Methods: Fungi and Bacteria. Minneapolis, Burgess, $239 \mathrm{p}$.

VEIGA, F.M., 1956. Notas sobre o raquitismo das socas em Campos. Brasil Acucareiro, Rio de Janeiro, 47:81-83. 
WAGGONER, P.E. e A.E. DIMOND, 1954. Reduction in waterflow by myceilium in vessels. American Joumal of Botcony, Lancaster, 41:637-640.

WAGGONER, P.E. e A.E. DIMOND, 1955. Produetion and role of extracellular pectic enzymes of Fusarium oxysporium 6. lycopersici. Phitopathology, Lancaster, $45: 79-87$.

WISMER, C.A. e R. URATA, 1967. Ratoon Stunting disease. Annual Report. Howaiian Sugar Planters' Association, Honolulu, p.37.

WORLEY, J.F., e A.G. GILLASPIE Jr., 1975. Electron microscopy "in situ" of the bacterium associated with ratoon stunting disease in Sudan-grass. Phytopathology, Lancaster, 65:287-295. 
.72.

APENDICE 


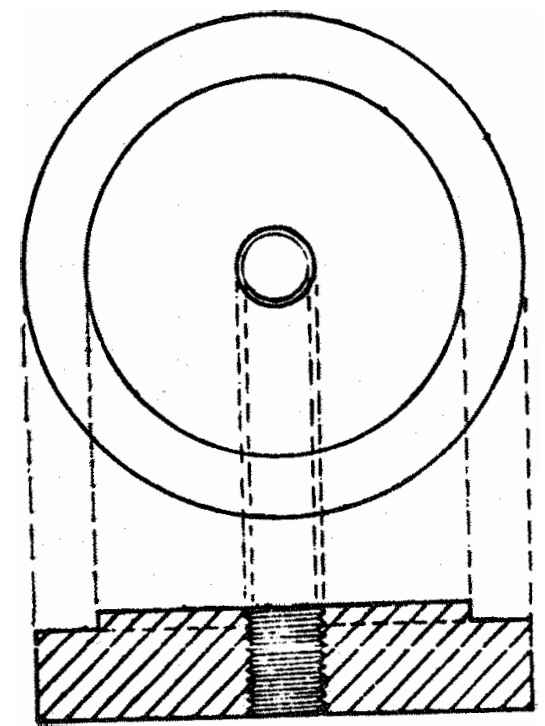

\section{BASE}
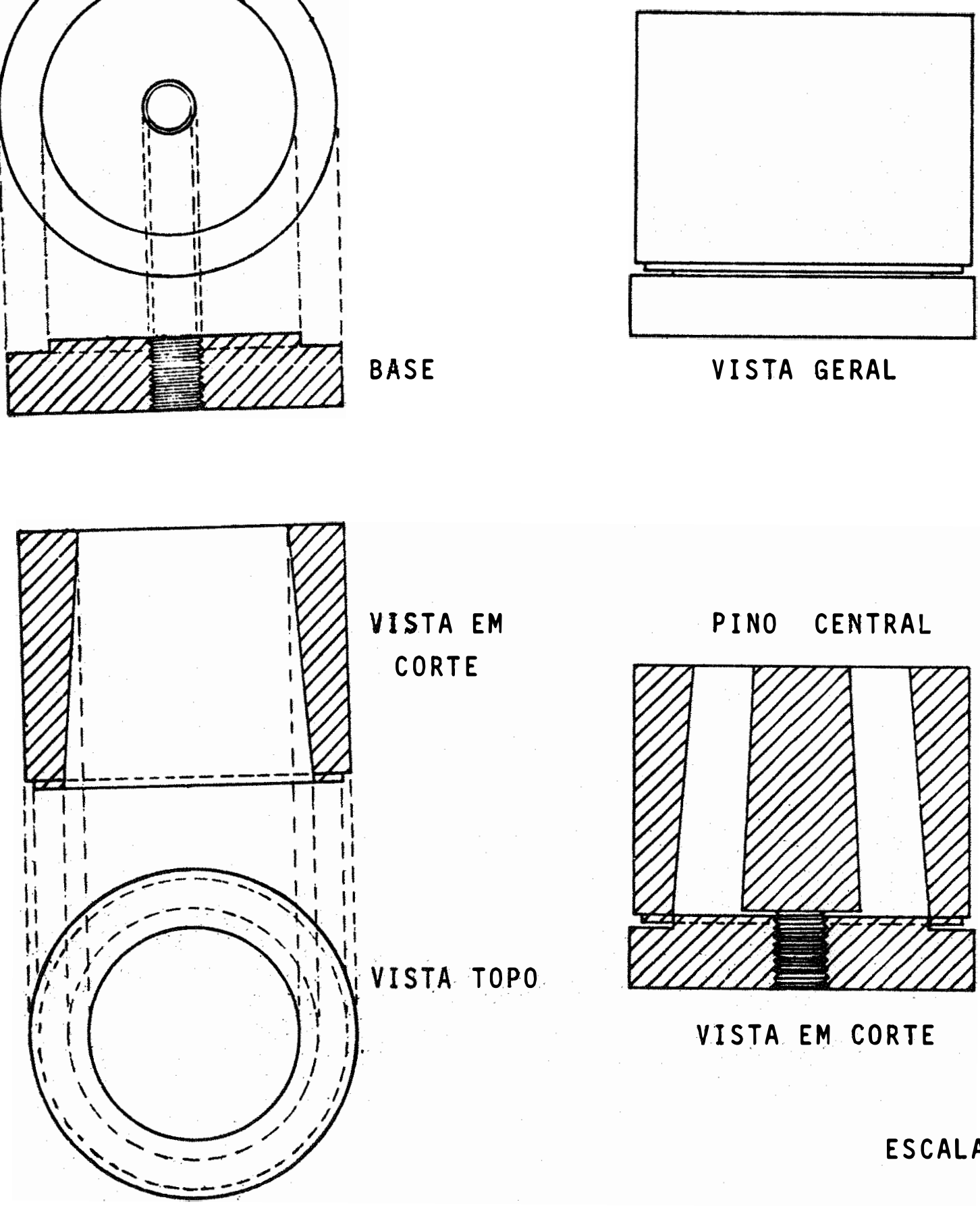

PINO CENTRAL

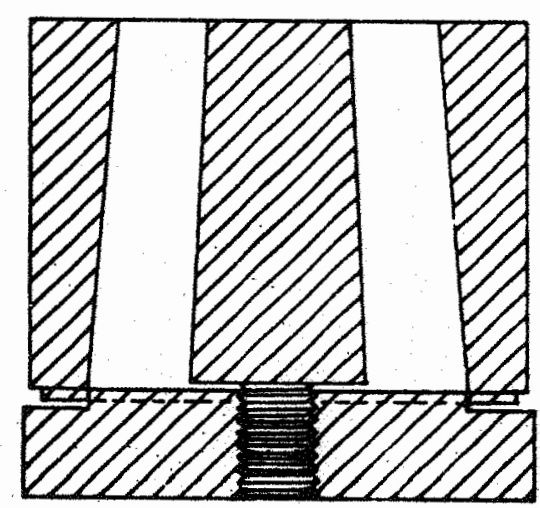

VISTA EM CORTE

ESCALA $1: 2$

APENDICE 1. MOLDE DE AÇO PARA FABRICAÇAO DE LUVAS DE BORRACHA EM DIAMETROS VARIAVEIS 
.74 .
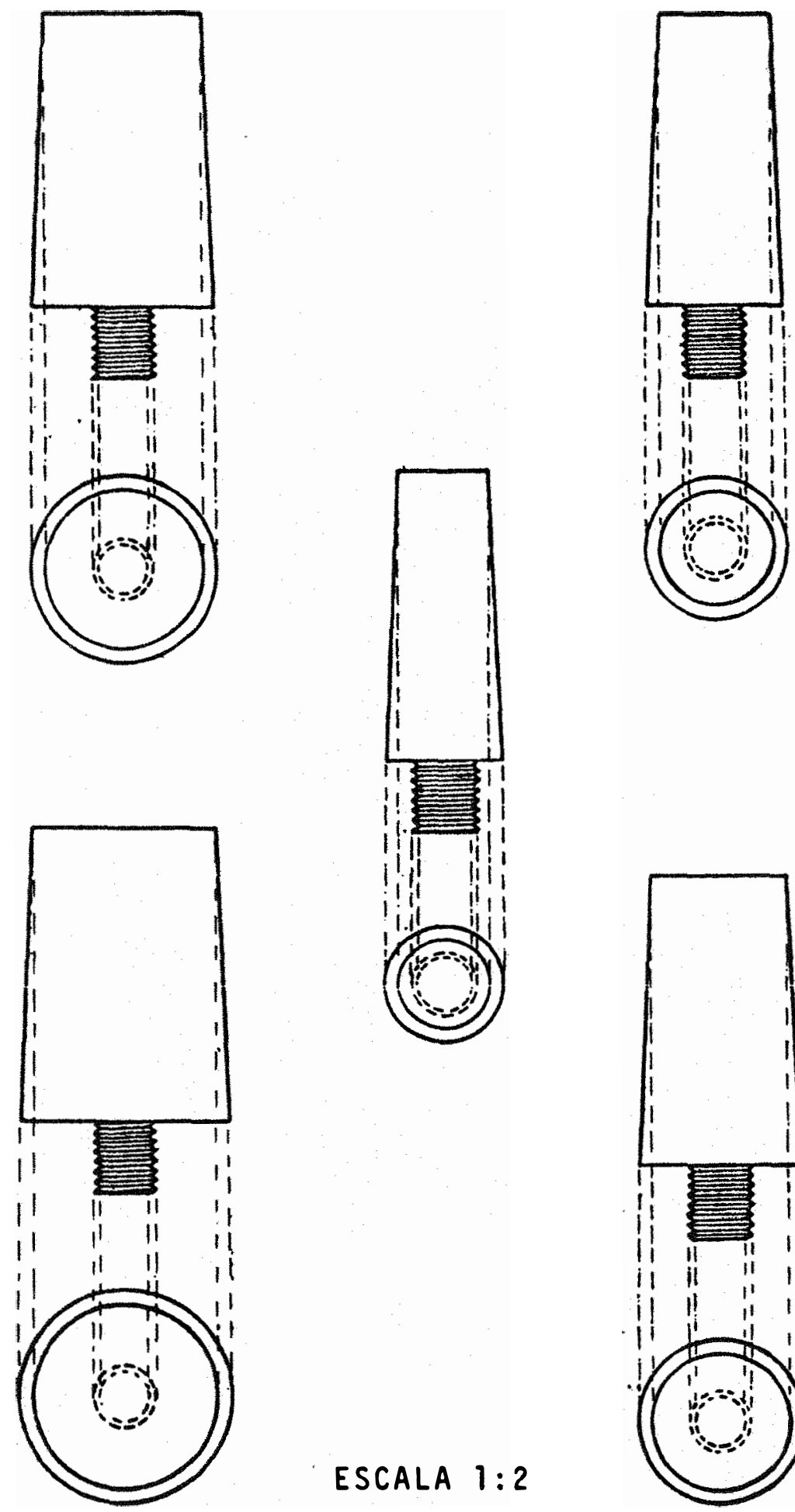

ESCALA $1: 2$

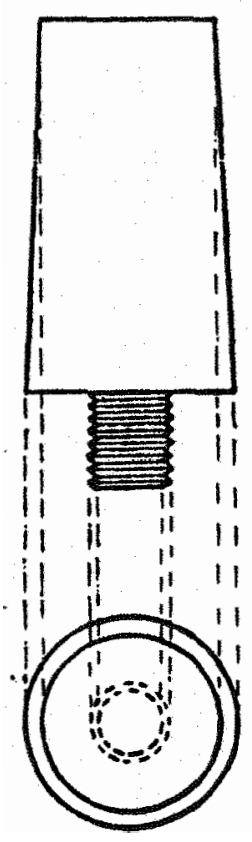

APENDICE 2. PINO.CENTRAL EM DIAMMETROS VARIATVEIS DO MOLDE DE BORRACHAS - 


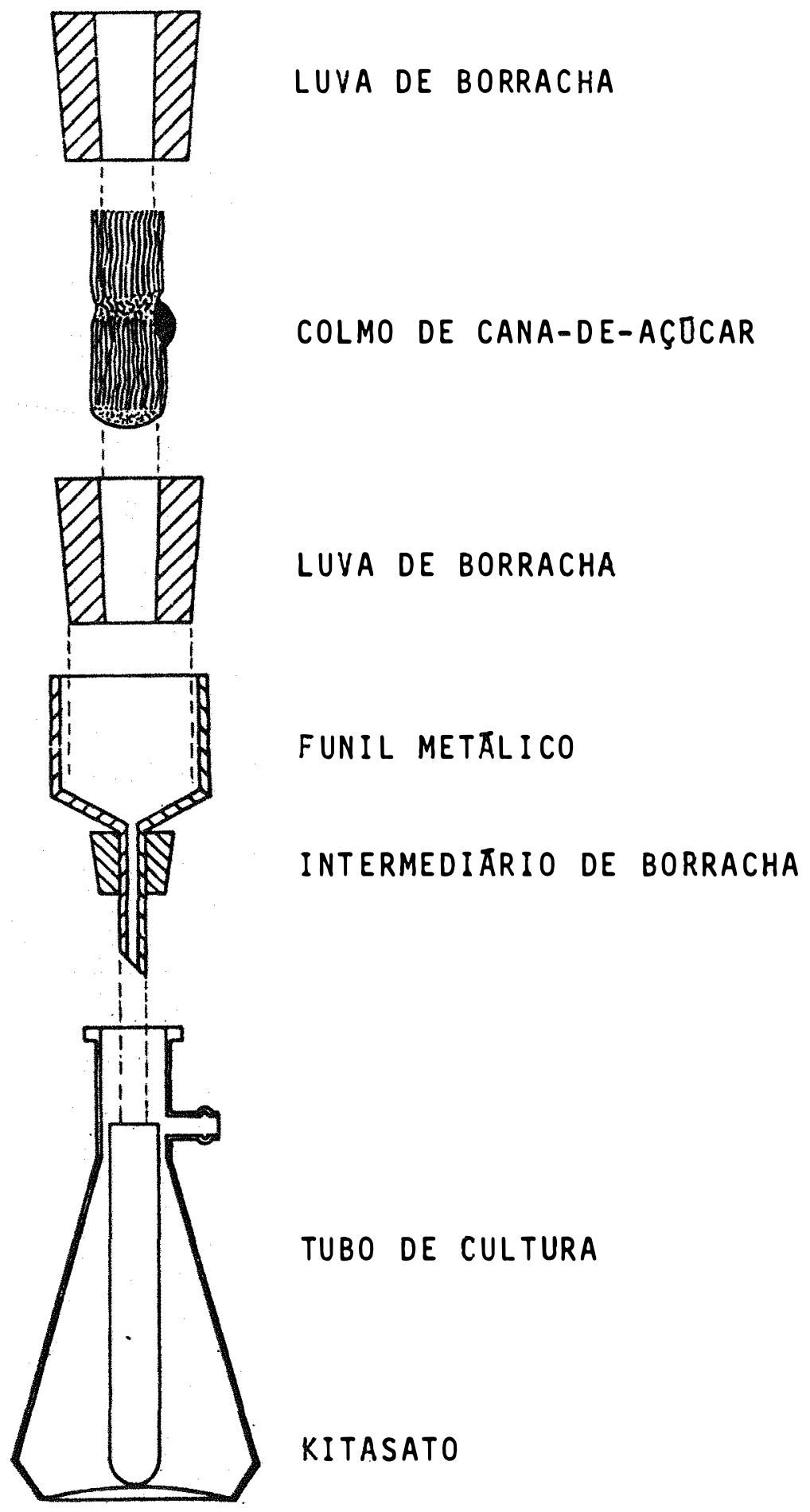

ESCALA $\quad 1: 4$ 
.76.

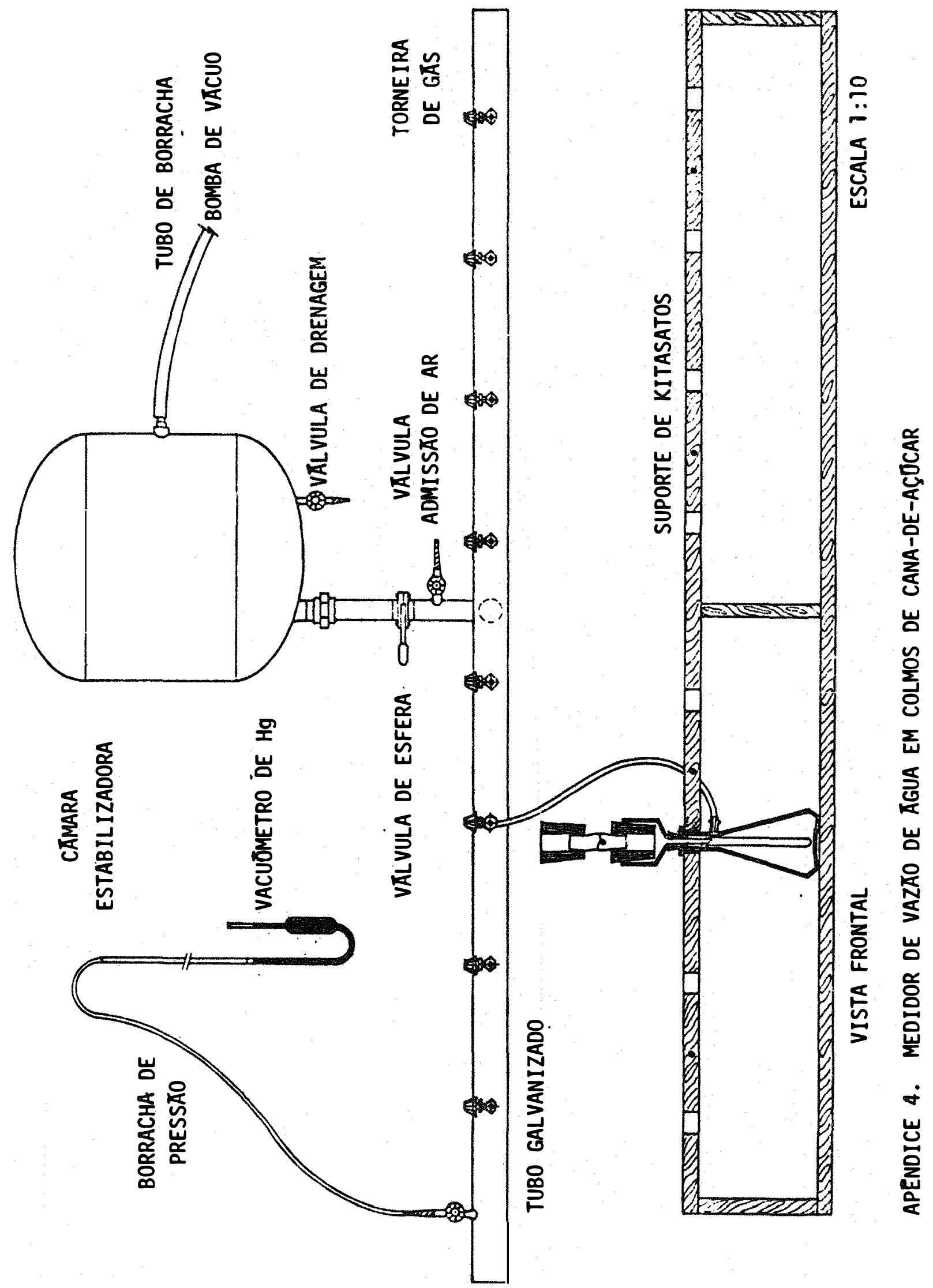




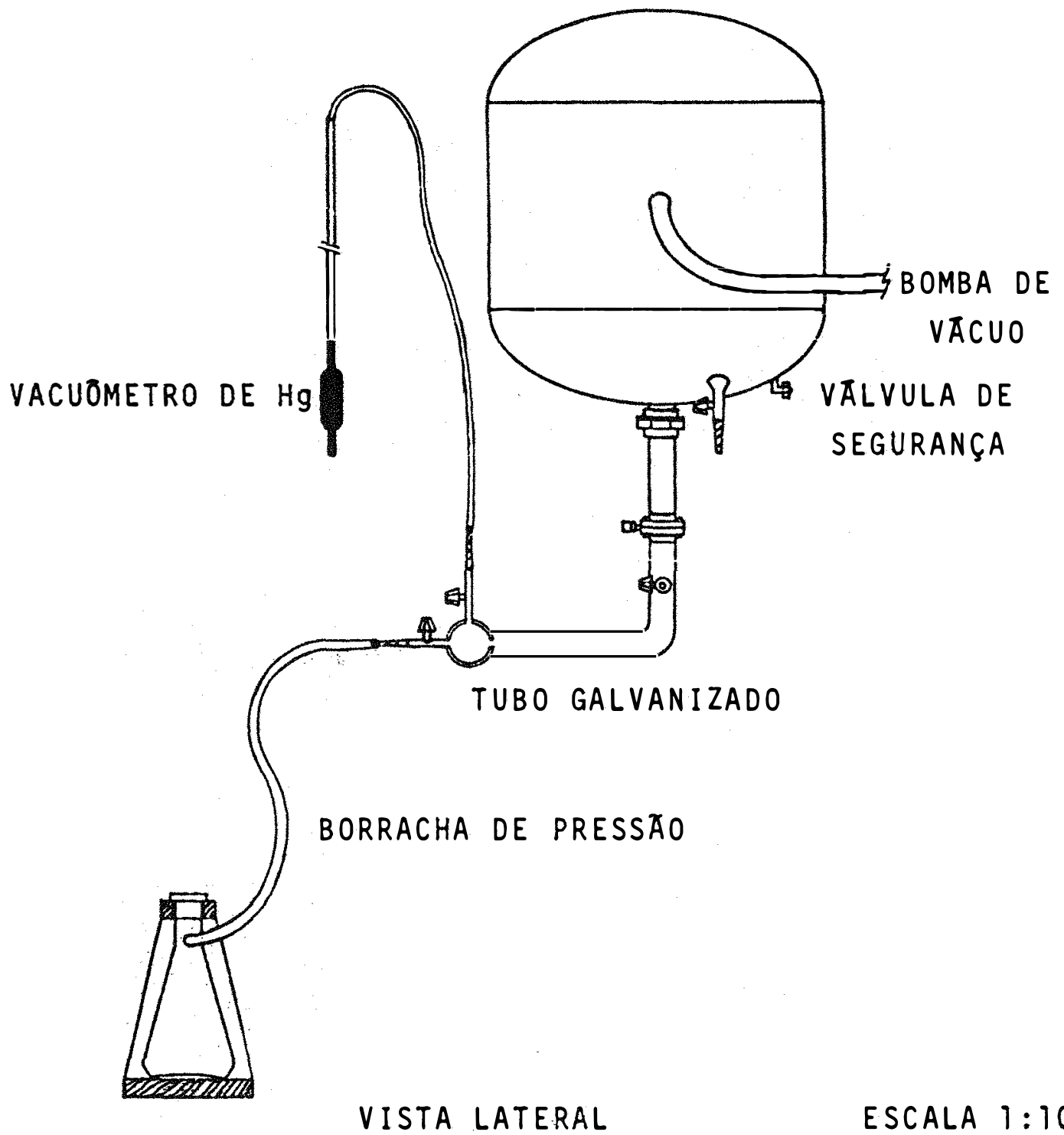

APENDICE 5. MEDIDOR DE VAZAO DE AGUA EM COLMOS DE CANA-DE-AÇOCAR 


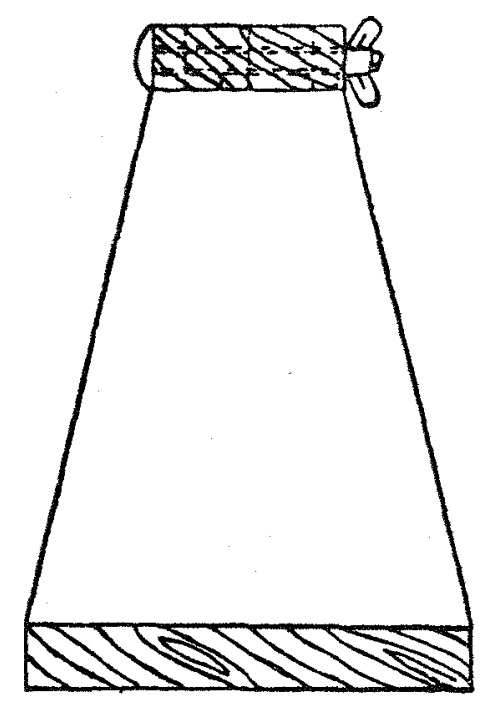

\section{VISTA LATERAL}

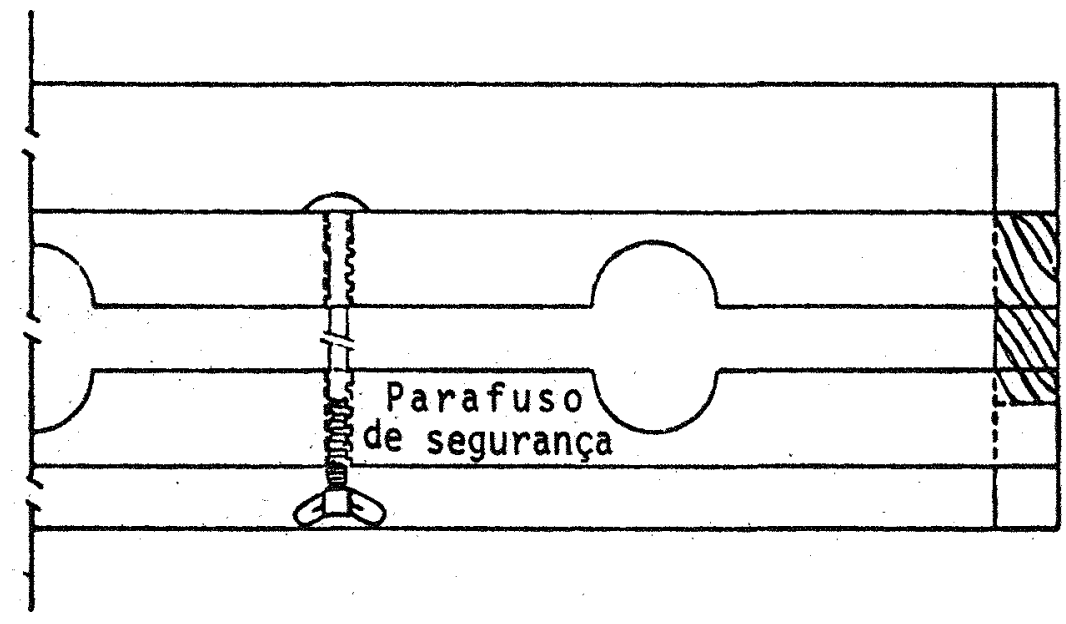

VISTA SUPERIOR

ESCALA 1:2 